Ks. Piotr PACIOREK*

\title{
CZAS KRESU CZASÓW W LITERATURZE APOKALIPTYCZNEJ
}

Czas i przestrzeń stanowią dwa wektory ziemskiego życia człowieka. Bardzo dyskusyjne obecnie pozostaje zastosowanie greckiego rozróżnienia czasu rozumianego jako trwanie ( $\chi \rho$ óvos) od czasu rozumianego jako wypełnienie

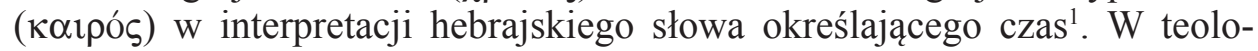
gicznej perspektywie sensem czasu jest więc zbawcza działalność Boga. Od początku aż do końca historii biblijnej czas jest środkiem dla Bożego dzieła zbawienia. Stąd też dla autora biblijnego historio-zbawcza koncepcja świata pojawia się przed jego koncepcją metafizyczną; widoczne jest to już w opisie siedmiu dni początków świata z Księgi Rodzaju, a co zostało wyrażone w Księdze Koheleta mówiącej, że wszystko zależy od czasu, a czas jest wyznaczony przez Boga (por. Koh 3, 1-17). Historia stworzenia świata ukazuje logikę czasu przy pomocy określeń światła i ciemności, co zmusza człowieka do wyznaczonej mu przez Boga dyscypliny życia kształtującej jego charakter $^{2}$. Według teologicznej koncepcji świata początek czasu wiąże się z dziełem stwórczym Boga ${ }^{3}$. W apokaliptycznej wizji świata dzieło stwórcze związane jest z dziełem zbawienia. Samo zaś eschatologiczne zbawienie ukazywane jest w literaturze apokaliptycznej przy pomocy literackiej metafory, symboliki biblijnej oraz alegorii.

W Piśmie Świętym doszukiwać się będziemy profetycznych znaków przyszłych wydarzeń (prophetica indicia praecedentia futurorum ${ }^{4}$ ). Wypowiedzi biblijne dotyczące przyszłości posiadają bowiem charakter symboliczno-eschatologiczny. Jakie jest teologiczne stanowisko wobec tego, co Pismo Święte nazywa „czasem ostatecznym” i wiążącymi się z nim wydarzeniami

${ }^{*}$ Ks. dr Piotr M. Paciorek - wykładowca teologii w St. John Vianney College Seminary, Miami, Florida, USA; e-mail: pacvin2003@yahoo.com.

${ }^{1} \mathrm{Na}$ temat kwestii czasu i miary czasu zob. Augustinus, De civitate Dei XII 16, ed. M. Dulaey - G. Madec, BAug 35, Paris 1993, 200-203 oraz G. Bardy, Notes, w: BAug 35, 471-476; P. Tillich, Systematic Theology, III/5: History and the Kingdom of God, Chicago 1967, 369-372.

${ }^{2}$ P.S. Minear, New Testament Apocalyptic, Nashville 1983, 54.

${ }^{3}$ Augustinus, De Genesi ad litteram V 5, ed. J. Zycha, CSEL 28/1, Pragae - Vindobonae Lipsiae 1894, 145-146 = Prosper Aquitanus, Liber sententiarum 281, ed. M. Gastaldo, CCL 68A, Turnhout 1972, 325: „Factae creaturae motibus coeperunt currere tempora”.

${ }^{4}$ Augustinus, De civitate Dei XIII 21, BAug 35, 312-313. 
eschatologicznymi, kiedy to świat immanentny „zetknie się” ze światem transcendentnym? Jak należy zrozumieć rzeczywistość kryjącą się pod terminem „czas ostateczny”, negującą wieczność świata materialnego? Poszukując tzw. duchowego sensu [określenie św. Pawła, który mówi o „rozumieniu duchowym" (Kol 1,9)], niniejsze biblijno-patrystyczne studium powinno dać odpowiedź na te i im podobne pytania. Wielu starożytnych i średniowiecznych teologów zastanawiało się nad wydarzeniami poprzedzającymi koniec materialnego świata. Wśród nich znajduje się Augustyn, biskup Hippony, który w Liście 199, skierowanym do Hezychiusza, noszącym tytuł O końcu wieku (De fine saeculi) stara się racjonalnie wyjaśnić ten problem 5 .

Rozważania biblijne dotyczące czasów ostatecznych koncentrują się na wierze w przyszłe życie, a przede wszystkim na relacji człowieka do Boga. Chrześcijanin bowiem zwraca się w kierunku przyszłości z poczuciem bezpieczeństwa, ponieważ już teraz posiada jej zadatek. Wiara w przyszłe życie wyzwala człowieka z miłości i przywiązania do życia ziemskiego, które jest przejściowe, zmienne, a także z lęku przed ostatnim dniem ${ }^{6}$. Według chrześcijańskiej eschatologii apokaliptycznej koniec będzie nie tylko wielkim zamieszaniem, lecz przede wszystkim uporządkowaniem wszechrzeczy i objawieniem rzeczywistości obecnej i działającej już teraz w świecie. Czasy ostateczne (futura tempora ${ }^{7}$ ), „wieczne czasy” (por. Jdt 15, 10; 2Tm 1, 9) stanowią wezwanie, aby każdy dokonał osobistego wyboru od którego zależy jego ,życie wieczne”, czyli zbawienie dotyczące tak terażniejszości jak i przyszłości eschatologicznej, lub ,wieczna śmierć” - określone biblijnym terminem „rzeczy ostateczne” (Syr 48, 24). Jesteśmy świadomi, że biblijna wizja starożytnego świata, ograniczonego czterema krańcami, nie jest taką samą, jaką przyjęło późne średniowiecze i nazwało przy pomocy określenia „okręgu ziemi”. Starożytne formuły apokaliptyczne dostosowane bowiem były do ówczesnego systemu świata, związanego z czterema punktami kardynalnymi oraz do czterech istotnych jego elementów lub żywiołów, jakimi są: ziemia, powietrze, woda i ogień ${ }^{8}$.

Szczególnie w okresie obejmującym lata 200 prz. Chr. do 150 po Chr. pojawiały się w pewnych żydowskich i chrześcijańskich kręgach, wśród Esseńczyków, pisma profetyczne zwane apokalipsą. Następowała akomodacja niektórych starożytnych symboli i liczb apokaliptycznych, których pole znaczeniowe zostało rozszerzone lub pomniejszone. Większość jednak formuł, wyrażeń, symboli apokaliptycznych weszła do biblijnej literatury apokaliptycznej, przekazując szeroką różnorodność przesłania o ziemskim i niebiańskim królestwie. Niektóre tylko apokalipsy ogłaszały wydarzenia związane z kresem czasu, większość zaś przekazywała elementy nowego spojrzenia na

\footnotetext{
${ }^{5}$ Tenże, Epistula 199, ed. A. Goldbacher, CSEL 57, Vindobonae - Lipsiae 1911, 243-292.

${ }^{6}$ Por. tenże, Enarrationes in PS. 147, 3, ed. E. Dekkers - J. Fraipont, CCL 40, Turnhout 1956, 2140.

${ }^{7}$ Tenże, Epistula 197, 4, CSEL 57, 234.

${ }^{8}$ Por. Victorinus Poetovionensis, De fabrica mundi 3, ed. M. Dulaey, SCh 423, Paris 1997, 140.
} 
historię, dlatego też zwano je apokaliptyczną eschatologią proponującą apokaliptyczną wizję historii określaną w średniowieczu czasem od Adama do końca świata. Podporządkowanie zaś historii zbawczemu działaniu Boga sprawia, że w wizjach apokaliptycznych widziano tzw. ,znaki czasu”. To zdeterminowane apokaliptyczne widzenie świata (dualistyczne) posiada swój teologiczny charakter. Dla autora apokalipsy histora nie jest przypadkową sukcesją wieków lub wydarzeń, których cel jest niezrozumiały, lecz sceną na której toczy się konflikt między dobrem a złem zmierzający do ostatecznej konkluzji, do końca nadającego znaczenie dla całości. Apokaliptyczne wizje określone potrójnym schematem: upadek - sąd - wynagrodzenie przekonywująco wyrażają moc i dobroć Boga, ostateczny wyrok nad Jego nieprzyjaciółmi oraz ocalenie sprawiedliwych sług Bożych ${ }^{9}$. Dlatego też nie można zrozumieć architektury średniowiecznych katedr oraz dzieł sztuki chrześcijańskiej zdobiących je, bez znajomości biblijnej Księgi Apokalipsy, której symbolika eschatologiczna kształtowała teologiczną myśl wielu wieków; sztuka bowiem chrześcijańska była zawsze odbiciem myśli teologicznej. Znakomitym przykładem jest teologia historii Joachima z Fiore (1135-1202), opata cystersów w Corazzo, z jej dominującą symboliką opartą na Apokalipsie ${ }^{10}$. Wśród terminów charakterystycznych dla ksiąg apokaliptycznych występuje termin „kres czasów” służący za punkt wyjścia do wszelkich rozważań eschatologicznych. Wierzenia świata pogańskiego, astrologia pogańska ${ }^{11}$, całkowite zdeterminowanie życia ludzkiego przez gwiazdy (stoik Posydoniusz ${ }^{12}$ ), przeznaczenie nie do

\footnotetext{
${ }^{9}$ Por. Minear, New Testament Apocalyptic, s. 51. Na temat kompozycji Apokalipsy i jej struktury zob. U. Vanni, La struttura letteraria dell'Apocalisse, Brescia 1980.

${ }^{10}$ Por. Joachim de Flore, Expositio in Apocalypsim, ed. K.V. Selge: Gioacchino da Fiore, Introduzione all'Apocalisse, prefazione e testo critico di K.V. Selge, traduzione di G.L. Potesta, Roma 1995. Zob. B. McGinn, The Calabrian Abbot: Joachim of Fiore in the History of Western Thought, New York 1985.

${ }^{11}$ Por. Ptolemaeus, Tetrabiblos III 13, 154-168, ed. G.P. Goold, The Loeb Classical Library (= LCL) 435, Cambridge Mass. 1940, 332-363; tamże III 14, 168-173, LCL 435, 362-373; Cicero, De fato 3, 6, ed. A. Yon: Cicéron, Traité du destin, Paris 1997, 4; tamże 17, 39, ed. Yon, s. 20); tamże 17, 40, ed. Yon, s. 20-21; Iustinus Martyr, Apologia I 43, ed. Ch. Munier, SCh 507, Paris 2006, 240; tenże, Apologia II 7, ed. Ch. Munier, SCh 507, 334-338; Clemens Alexandrinus, Stromata III 7, ed. L. Früchtel, GCS 52, Berlin 1960, 223-224; Origenes, Philocalia 23, 1, ed. M. Harl, SCh 226, Paris 1976, 130-132; Tatianus, Oratio adversus Graecos 11, PG 6, 829-830; Origenes, In Iesu Nave hom. 5, 6, ed. A. Jaubert, GCS 30, Leipzig 1920-1921, 318-321; Eusebius Caesariensis, Praeparatio evangelica III 4, 3, ed. É. des Places, SCh 228, Paris 1976, 166-168; VI 9, 32, SCh 266, 212; VI 11, 1-2, SCh 266, 234; Basilius Caesariensis, Commentarius in Isaiam prophetam 7, 191, PG 30, 447448A; 13, 275, PG 30, 601-604; Didymus Alexandrinus, Commentarii in Octateuchum et Reges 37, ed. P. Nautin - L. Doutreleau, SCh 233, Paris 1976, 98; Epiphanius, Panarion 5, 3, ed. K. Holl, GCS 25, Berlin 1915, 184-5; 16, 3, GCS 25, 212; Hieronymus Stridonensis, Commentariorum in Hiezechielem VI 20, 1, ed. F. Glorie, CCL 75, Turnhout 1964, 255; Augustinus, Enarrationes in Ps. 58(1), 14, CCL 39, 740; tamże 73, 18, CCL 39, 1017; tenże, Sermones de Vetere Testamento 20, 2, ed. C. Lambot, CCL 41, Turnhout 1961, 263; 29, 3, CCL 41, 374.

${ }^{12}$ Por. Augustinus, De civitate Dei V 2, BAug 33, Paris 1960, 648-653; tenże, Enarrationes
} 
uniknięcia (Demokryt, Heraklit, Empedokles, Arystoteles ${ }^{13}$ ) dodawały konkretne szczegóły do świadomości autorów literatury apokaliptycznej, która powstawała w czasach zdominowanych przez filozofię stoicką ${ }^{14}$. Środowisko hellenistyczne, zwane światem grecko-rzymskim, mocno naznaczonym przez fatum $^{15}$, pojmowane w religii rzymskiej jako uosobienie losu i konieczności, starało się odczytać symbole liczbowe w odniesieniu do konkretnego czasu i określonej nimi ilości. Apokaliptyka judeo-chrześcijańska przejęła te symbole, jednak jej zadaniem było ukazanie rzeczywistości materialno-duchowej. Terminologia biblijna taka jak „kres”, czy „koniec” posiada nie tylko swój wymiar materialny, widzialny, zewnętrzny, lecz także wymiar duchowy, wewnętrzny, a przede wszystkim mesjański. W tym też sensie należy rozumieć termin biblijny „koniec świata” (Mt 13, 39-40. 49; Mt 24, 3; Mt 28, 20). Przepowiednie wymienione w Piśmie Świętym, posługujące się formułami i symbolami apokaliptycznymi oraz ukazywane przy pomocy prorockich wizji zapowiadają „kres czasów” (Mi 4, 1; 1Kor 10, 11) lub „koniec czasu” (Dn 12, 9), czy „koniec dni” (Dn 12, 13; Oz 3, 5), w wymiarze materialnym związane są z powtórnym nadejściem Mesjasza i zakończeniem ziemskiego życia człowieka oraz zbawczego działania Boga w czasie.

Charakterystyczne dla biblijnej literatury apokaliptycznej są symbole liczbowe, takie jak: ,czterdzieści dwa miesiące”, ,trzy i pół roku” (Ap 11, 9. 11), „tysiąc lat” (Ap 20, 2. 4-7), liczba 666, „sto czterdzieści cztery tysiące, mające imię [Baranka] i imię Jego Ojca wypisane na czołach [i] wykupionych z ziemi” (Ap 14,1.3) oraz wydarzenia eschatologiczne jak: „wielkie prześladowanie”, „,wielki ucisk” (Ap 7, 14), ,apostazja”, ,zburzenie Jerozolimy”, „ohyda i odraza” lub „ohyda ziejąca pustką” (Dn 9, 27; Dn 11, 3; Dn $12,11)$. W wizjach prorockich, dotyczących zwłaszcza czasów następujących po Zmartwychwstaniu Chrystusa, pojawiają się postaci osobowe takie jak: ,antychryst” (1J 2, 18. 22; 1J 4, 2-3; 2J 7), ,fałszywi prorocy” (2P 2, 1), „fałszywi nauczyciele” (2P 2, 1), „Gog i Magog”. Wizje prorockie dotyczą zasadniczo kosmicznych katastrof spowodowanych przez spadające komety i asteroidy, a także kataklizmów ziemskich, wywołanych przez cztery ele-

in Ps. 72, 22, CCL 39, 997-998; tamże 31(2), 16, CCL 38, 236-237; Prudentius, Contra orationem Symmachi II 471-481 ed. H.J. Thomson, LCL 398, Cambridge Mass. 1954, 42-43.

${ }^{13}$ Cicero, De fato 17, 39, ed. Yon, s. 20.

${ }^{14}$ Diogenes Laertius, Vitae philosophorum VII 1, 135 ed. R.D. Hicks, LCL 185, Cambridge Mass. 1925, 240-241; Plotinus, Enneades II 3, 1 ed. J. Henderson, Greek Text with an English Translation by A.H. Armstrong, LCL 441, Cambridge Mass. - London 2000, 56-59; III 1, 2, LCL 442, 12-15); Julianus Imperator, Epistula 50, 444A, ed. W.C. Wright, LCL 157, Cambridge Mass. 1923, 158-159.

${ }_{15}^{15}$ Por. Minucius Felix, Octavius 36, PL 3, 365-367; Iustinus Martyr, Apologia I 43, SCh 507, 240-242; tenże, Apologia II 6(7), 3, SCh 507, 336; Tatianus, Oratio adversus Graecos 7, PG 6, 819820; Gregorius Nyssenus, Contra Fatum, ed. J.A. McDonough, GNO III/2, Leiden 1987, 29-63. 
menty świata (elementa mundi ${ }^{16}$ ) do których należą ziemia, powietrze, woda i ogień ${ }^{17}$.

Wszelkie proroctwo zawarte w Piśmie Świętym nie ukazuje jedynie przyszłosci, ale także przeszłość i teraźniejszośćc ${ }^{18}$. Punktem wyjścia zapowiedzi eschatologicznych były u proroków wypadki współczesne, zwiastujące bliskie ich nadejście, na przykład zapowiedź bliskiego końca przez proroka Ezechiela (Ez 7, 1-14). Czy „kres czasów” dotyczy tzw. „epoki pogan”, która trwać miałaby według Pisma Świętego ,czterdzieści dwa miesiące”, co wynosi „trzy i pół roku” (Ap 11, 9. 11), która nastąpi po „tysiącletnim” królowaniu Mesjasza? „Epoka pogan”, ogólnie mówiac, oznacza epokę, która odrzuciwszy prawo Boże i jednocześnie porządek z niego wynikajacy, została zdominowa-

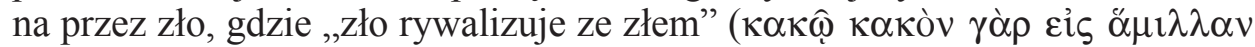

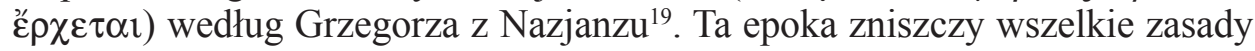
ładu społecznego chrześcijan, wśród których dominują dwie zasady, pierwsza głosząca „nie odpłacać złem za zło” (Rz 12, 17; 1Tes 5, 15; 1P 3, 9; por. Iz 1, 16-17) oraz druga - „odpłacać dobrem za zło”, co jest według Augustyna wyrazem miłosierdzia ${ }^{20}$, a wynika z nauki o miłości nieprzyjaciół (Mt 5, 44; Łk 6, 27-28. 35). W sensie moralnym ,kres czasów” oznacza kres zła, które jest konsekwencją „,bezprawia”, prowadząc do refleksji nad zbawieniem tego świata.

Temat niniejszy analizować będziemy w dwóch zasadniczych aspektach, w aspekcie chrystologicznym i eklezjologicznym. Chrystus bowiem ukazuje się w całej swej pełni, w relacji do świata i do Kościoła, jako Stwórca, Zbawiciel i Sędzia. Wyrażone to zostało w sposób adekwatny biblijnym zdaniem „Jezus Chrystus wczoraj i dziś, ten sam także na wieki” (Hbr 13, 8). W tej wypowiedzi dostrzegamy trójstopniowość, którą wyrazić możemy przy pomocy terminów Proto-Ewangelia, Ewangelia doczesna i Ewangelia wieczna, rozumiejąc Chrystusa jako wypełnienie objawienia. Zgodnie z powiedzeniem Grzegorza Wielkiego, codziennie odczytuje się Ewangelię, głosząc życie przyszłe $^{21}$. Na płaszczyźnie retorycznej, Ewangelia rozumiana jest jako metonimia Chrystusa, zwłaszcza że Chrystus, Odwieczne Słowo Boże, i Ewangelia, proklamacja (kerygma) Słowa Bożego w języku św. Pawła są używane na oznaczenie objawienia się Słowa Bożego. Ze względu na jej egzortatywny

\footnotetext{
${ }^{16}$ Por. Tertullianus, Adversus Hermogenem 30-32, ed. F. Chapot, SCh 439, Paris 1999, 158-168; P. Aaësse - A. Solignac, Notes complementaires, w: BAug 48, Paris 1972, 660-668.

${ }^{17}$ Por. P. de Laubier, Le Temps de la fin des temps. Essai sur l'eschatologie chrétienne, Paris 1994.

${ }^{18}$ Por. Gregorius Magnus, Homiliae in Hiezechielem prophetam 1, 1, ed. Ch. Morel, SCh 327, Paris 1986, 50. Na temat proroków zobacz Pwt 18, 15-22 oraz Chrystus jako prawdziwy prorok J 6, 14; J 7, 40; Dz 3, 22; Dz 7, 37.

${ }^{19}$ Gregorius Nazianzenus, Christus Patiens 42, ed. A. Tuilier, SCh 149, Paris 1969, 130.

${ }^{20}$ Augustinus, Enarrationes in Ps. 108, 4, CCL 40, 1586; tamże. 118(7), 1, CCL 40, 1682-1683; tenże, Liber de divinis scripturis sive speculum 16, ed. F. Weihrich, CSEL 12, Vindobonae 1887, 376-379.

${ }^{21}$ Gregorius Magnus, Homiliae in Hiezechielem prophetam II 4, 14, ed. Ch. Morel, SCh 360, Paris 1990, 212.
} 
aspekt, literatura apokaliptyczna zaliczana jest nie tylko do literatury profetycznej, lecz także do literatury mądrościowej. Czas kresu czasów posiada swój wymiar czasowy i eschatologiczny, a raczej sens eschatologiczny. Wchodzimy w tzw. filozofię czasu i teologię czasu. Dlatego też myślimy o historio-zbawczej funkcji czasu oraz o egzystencji pozaczasowej, „duchowej”, nie zdeterminowanej czasem. Zbawienie bowiem dokonuje się w historii, która nadaje wszelkim bytom prawdziwy charakter, ponieważ historia została zapoczątkowana przez Boga i ta transcendentna historia, zwana wiecznością, staje się obecna w świecie dostrzegalnym przy pomocy zmysłów.

Warunek kresu czasów został przedstawiony przez samego Chrystusa w przemówieniu eschatologicznym: „A ta Ewangelia o królestwie będzie głoszona po całej ziemi, na świadectwo wszystkim narodom. I wtedy nadejdzie koniec" (Mt 24, 14). Według Augustyna, ponieważ data końca świata jest nieznana dla ludzi, najlepszym sposobem na to, ażeby się co do niej nie pomylić, jest nie tylko bycie zawsze przygotowanym na przyjście Chrystusa, ale również pragnienie Jego przyjścia ${ }^{22}$. Wydaje się, że ta prorocka przepowiednia Chrystusa wskazuje na kres Ewangelii doczesnej, otwierając jednocześnie bramy do wiecznej Ewangelii. Apokalipsę zas będziemy traktować jako kontynuację i dopełnienie eschatologicznego i mesjańskiego wymiaru Ewangelii, i nie tylko Ewangelii, ale jako konkluzję zapowiedzi prorockich. Pozostaje to wyrażone niejako w formie przestrogi w samym epilogu Apokalipsy: „Ja świadczę każdemu, kto słucha słów proroctwa tej księgi: jeśliby ktoś do nich cokolwiek dołożył, Bóg mu dołoży plag zapisanych w tej księdze. A jeśliby ktoś odjął co ze słów księgi tego proroctwa, to Bóg odejmie jego udział w drzewie życia i w Mieście Swiętym - które są opisane w tej księdze" (Ap 22, 18-19). Wypowiedź ta przypomina przestrogi i zaklęcia dołączane do formuł prawnych pochodzących ze starożytnych dokumentów mezopotamskich i egipskich. Św. Piotr wyjaśnił zaś, że: ,żadne proroctwo Pisma nie jest dla prywatnego wyjaśniania. Nie z woli bowiem ludzkiej zostało kiedyś przyniesione proroctwo, ale kierowani Duchem Świętym mówili od Boga święci ludzie" (2P 1, 20-21). Św. Paweł zwięźle wyraził to, mówiąc do wiernych mieszkających w Tesalonice, stolicy Macedonii: „proroctwa nie lekceważcie” $(1$ Tes 5,20$)$. W podobnym tonie jest wypowiedź z Księgi Ezechiela: „Nadchodzą dni, gdy każde widzenie stanie się rzeczywistością" (Ez 12, 23). Zasadniczym zadaniem proroków było ostrzeganie przed karą, upominanie, a nawet i groźby, oraz zachęta do wierności przykazaniom Bożym.

\section{CHRYSTUS, ODWIECZNY DZIEŃ BOŻY}

Łacińska biblijna terminologia dies dominica, dies aeterna i dies irae zawiera w sobie myśl chrystocentryczną i eklezjocentryczną. Dotyczy ona bowiem całego „misterium” Chrystusa „zasiadającego po prawicy Boga” (Ps

\footnotetext{
${ }^{22}$ Augustinus, Epistula 199, 13. 52-53, CSEL 57, 289-291.
} 
110 [109], 1; Mt 22, 44; Mk 16, 19; Dz 2, 34; Rz 8, 34; Ef 1, 20; Kol 3, 1; Hbr $12,2 ; 1 \mathrm{P} 3,22)$. Przy pomocy tej terminologii wchodzimy w dziedzinę relacji Stwórcy do stworzenia, Boga Stwórcy do stworzonego świata zmierzającego do swej pełni (por. Ef 1, 23), czyli Kościoła w aspekcie eschatologicznym, gdzie „sprawiedliwi jaśnieć będą jak słońce w królestwie Ojca swego” (Mt 13, 43). Ta wypowiedź zanotowana w Ewangelii według św. Mateusza jest reminiscencją wypowiedzi z Księgi Daniela: „Mądrzy będą świecić jak blask sklepienia, a ci, którzy nauczyli wielu sprawiedliwości, jak gwiazdy przez wieki i na zawsze" (Dn 12, 3).

W jednym ze swoich przemówień, Grzegorz z Nazjanzu powiedział:

„[...] «Tym samym czym słońce jest dla świata zmysłowego, Bóg jest dla świata rozumnego» [...] W rzeczywistości, tak jak słońce daje światło dla oka, tak Bóg dla rozumowania człowieka; słońce należy do rzeczy najpiękniejszych w świecie widzialnym, Bóg zaś jest najpiękniejszy w świecie rozumowym" 23 .

Chrystus Bóg-Człowiek ukazany jest w symbolicznym kolorze metalu zwanego w języku francuskim „vermeil”, w języku angielskim ,gilded silver”, w języku polskim ,,pozłocone srebro" (Prz 23, 31; Pnp 5, 10-11; Mdr 13, 14; Iz $5,2 ; \mathrm{Lm} \mathrm{4}, 7 ; \mathrm{Ez} 1,4.27 ; 8,2 ; 23,14)$. Właściwie jest to stop złota ze srebrem, o kolorze błyszcząco-czerwonym. Papież Grzegorz Wielki uważa, że połysk stopu złota ze srebrem (Ez 1, 4. 27; 8, 2) oznacza Jezusa Chrystusa, Pośrednika miedzy Bogiem a człowiekiem. Sam zaś stop złota i srebra symbolizuje dwie natury w Jezusie Chrystusie: boską i ludzkąa ${ }^{24}$

1. Dies Dominica. Kres czasów, rozumiany jako „chwila, w której dokona się czas świata" (Tb 14, 5), w perspektywie eschatologicznej stanowi wejście w odwieczny „Dzień Boży”, to znaczy przejście z doczesności do wieczności, z immanencji do transcendencji. W Ewangelii według św. Jana „dzień ostateczny" (J 6, 39-40. 44. 54; 11, 24) pozostaje w łączności z sądem (J 12, 48) i zmartwychwstaniem. Jest to „dzień sądu” $(1 \mathrm{~J} 4,17)$ o którym mówi również św. Piotr w 2. liście (2P 2, 9; 3, 7; 3, 10). Dla św. Pawła, „dzień Pana Jezusa” (1Kor 5, 5) lub „dzień Pański” (1Tes 5, 1-2; 2Tes 2, 2) jest tym samym dniem sądu nazwanym „dniem Pana naszego Jezusa Chrystusa” (1Kor 1, 8; 2Kor 1, 14; Łk 10, 12). Każdy więc dzień Pański jest prototypem i antycypacją w eschatologicznym Dniu Pańskim, zwanym paruzją. W sensie biblijnym „dzień Pański” rozpoczął się Męką Jezusa Chrystusa i trwać będzie aż do końca, według Cezarego z Arles ${ }^{25}$. Dlatego ten dzień jest „dniem zbawienia”

${ }^{23}$ Gregorius Nazianzenus, Oratio 28, 30, ed. P. Gallay, SCh 250, Paris 1978, 168, thum. własne. Por. Plato, Respublica VI 508C, ed. J. Henderson, LCL 276, Cambridge Mass. 2000, 102-103.

${ }^{24}$ Por. Gregorius Magnus, Homiliae in Hiezechielem prophetam 2, 14, SCh 327, 102; 8, 25 , SCh $327,312$.

${ }^{25}$ Caesarius Arelatensis, Expositio in Apocalypsim 13, PL 35, 2448; 18, PL 35, 2460. 
(2Kor 6, 2), „,dniem odkupienia”: „I nie zasmucajcie Bożego Ducha Świętego, którym zostaliście opieczętowani na dzień odkupienia" (Ef 4, 30). Wyraźnie jest tu mowa o namaszczeniu (zob. 1J 2,18). Dla św. Piotra dzień ten jest początkiem „dnia wieczności” (2P 3, 18; Mi 5, 1). Chrystus w czasie Ostatniej Wieczerzy zapowiedział Apostołom dzień zmartwychwstania, że więcej już pić nie będzie tego wina $\mathrm{z}$ nimi, aż do owego dnia gdy pić go będzie w Królestwie Bożym (por. Mt 26, 29; Mk 14, 25). Ta zapowiedź znajduje swoje dopełnienie w deklaracji z Apokalipsy: „Błogosławieni, którzy są wezwani na ucztę Godów Baranka" (Ap 19, 9). Według Augustyna dzień Pański jest ósmym dniem, inaczej mówiąc dniem wiecznym (dominicus dies velut octavus aeternus), który należy rozumieć jako koniec bez końca (Ecce quod erit in fine sine fine $)^{26}$.

2. Dies aeterna. Wieczny dzień (dies aeterna), według Grzegorza Wielkiego, wieńczy siedem dni stanowiąc łącznie z nimi oktawę (octaua). Całość bowiem czasu wypełnia się w siedmiu dniach ${ }^{27}$. Historio-zbawczy sens czasu wyrażony przy pomocy symbolicznej liczby siedmiu dni, po których następuje dzień ósmy wiąże dzieło stworzenia z dziełem odkupienia i zbawienia. Stąd też liturgiczna octava zawiera w sobie tajemnice stworzenia i zbawienia. Augustyn utożsamił Słowo Stwórcze Boga z Chrystusem Zmartwychwstałym, którego nazwał „dniem”, ponieważ „Ten, który został nazwany dniem oddzielił światłość od ciemności" ${ }^{28}$. Łukasz zanotował w Ewangelii zapowiedź paruzji jako nastanie światłości na całym okręgu ziemi: „Bo jak błyskawica, gdy zabłyśnie, świeci od jednego krańca widnokręgu aż do drugiego, tak będzie z Synem Człowieczym w dniu Jego" (Łk 17, 24). Sam Chrystus, według biskupa Hippony, stanowi wieczny dzień (dies aeternus).

„[Chrystus] posiada swój dzień (narodzin) pośród wszystkich dni czasu, lecz on sam stanowi wieczny dzień pochodzący od dnia wiecznego"29.

„Ten dzień nie przemija, aby powrócić rok rocznie dzięki sukcesji czasów, jest on bez zachodu tak jak nastał bez wschodu jutrzenki. On więc jest tym jedynym Słowem Boga, życiem i światłością ludzi, który jest dniem wiecznym $[\ldots]^{p 30}$.

Studium Marguerite Harl wykazuje, w jaki sposób Ojcowie Kościoła połączyli „dzień Pański” ze zmartwychwstaniem Chrystusa ${ }^{31}$. ,Jezus Chrystus wczo-

${ }^{26}$ Augustinus, De civitate Dei XXII 30, BAug 37, Paris 1960, 718-719.

${ }^{27}$ Gregorius Magnus, Homiliae in Hiezechielem prophetam II 4, 2, SCh 360, 180-184.

${ }^{28}$ Augustinus, Tractatus in Joannis Evangelium 44, 9, ed. H. Savon, BAug 73B, Paris 1989, 28-9. Por. tamże 44, 16, BAug 73B, 38-9.

${ }^{29}$ Tenże, Sermo 190, 3, 3, PL 38, 1008.

${ }^{30}$ Tenże, Sermo 188, 2, 2, PL 38, 1004.

${ }^{31}$ Zob. M. Harl, Le déchiffrement du sens. Études sur l'herméneutique chrétienne d'Origène à 
raj i dziś, ten sam także na wieki" (Hbr 13,8) jest eschatologicznym dniem przeznaczonym dla człowieka.

Prorok Amos utożsamił „dzień Pański” z dniem sądu i kary: „Biada oczekującym dnia Pańskiego. Cóż wam po dniu Pańskim? On jest ciemnością a nie świattem" (Am 5, 18). Cezary z Arles przyrównał zaś ten dzień do dnia opanowania Jerozolimy przez Tytusa i Wespazjana ${ }^{32}$. Ta aluzja do historii rzymskiej znajduje się ponadto $\mathrm{w}$ jednym $\mathrm{z}$ jego kazań ${ }^{33}$. Aktualizacja przepowiedni prorockich i zastosowanie ich do historii rzymskiej było sprawą dość rzadką, niemniej znaną w literaturze wczesno-chrześcijańskiej.

\section{PARUZJA - POWTÓRNE PRZYJŚCIE CHRYSTUSA}

Obecny temat posiada swój bardzo mocny aspekt chrystologiczny i mesjański. To znaczy, że dzieje wszechświata zostały niejako uwarunkowane i uzależnione, określone i zdefiniowane egzystencją Słowa Bożego: stworzenie wyrażone według św. Jana w prologu jego Ewangelii: „Na początku było Słowo [...]. Wszystko przez Nie się stało" (J 1, 1-3); wypełnienie się czasów - narodzinami Syna Bożego, kres czasów - powtórnym przyjściem Syna Człowieczego zasiadającego ,po prawicy tronu Boga” (Mk 16, 19; Hbr 12, 2) i sądem Bożym. Można więc mówić o chrystologicznej wizji czasu, a także o chrystologicznej wizji wszechświata. Chrystus w Apokalipsie ukazany jest jako Alfa i Omega, Początek i Koniec (Ap 21, 6; 22, 13; 22, 19), Ten, który zna przeszłość i przyszłość ${ }^{34}$, ponieważ "lata [Jego] nie mają końca" (Ps 102[101], 28). Czas pełni czasów odnosi się do historycznego narodzenia Chrystusa w Betlejem, gdzie przybył z zamiarem miłosierdzia do człowieka. „Pełnia czasu” (Ga 4, 4) ukazuje misterium największej dobroci Bożej względem człowieka, jest to czas który nastąpił po czasie proroctw ${ }^{35}$. Czas zaś kresu czasów odnosi się do powtórnego przyjścia Chrystusa na ziemię, gdzie przybędzie z zamiarem sprawiedliwości, i odpłaci sprawiedliwym dobrem za dobro, bezbożnym zaś złem za zło ${ }^{36}$. Zapowiedziane w Ewangelii św. Jana powtórne przyjście Chrystusa jako „chwila w której uczniowie znów ujrzą Jego” (J 16, 16-33), zostało nazwane przez apostołów „dniem nawiedzenia” (1P 2, $12)$, lub „dniem objawienia” $(2 \mathrm{Tm} 4,8)$. „[...] tak i Chrystus raz jeden był ofiarowany dla zgładzenia grzechów wielu, drugi raz ukaże się nie w związku

Grégoire de Nysse, Collection des Études Augustiniennes. Série Antiquité 135, Paris 1993, 433-435 (rozdział pt. L'Éloge de la fête chrétienne).

${ }^{32}$ Por. Caesarius Arelatensis, Expositio in Apocalypsim 13, PL 35, 2448.

${ }^{33}$ Por. tenże, Sermo 127, 2, ed. G. Morin, CCL 103, Turnhout 1953, 525: „[...] et post quadraginta duos annos passionis dominicae, venerunt duo ursi, Vespasianus et Titus, et obsederunt Hierusalem".

${ }^{34}$ Por. tenże, Expositio in Apocalypsim 3, PL 35, 2429.

${ }^{35}$ Por. W.A. Meeks, Apocalyptic Discourse and Strategies of Goodness, „The Journal of Religion" 80 (2000) 461-475.

${ }^{36}$ Por. Augustinus, Enarrationes in Ps. 118(7), 1, CCL 40, 1682-1683. 
z grzechem, lecz dla zbawienia tych, którzy Go oczekują" (Hbr 9, 28). Hipolit, mówi o pierwszej i o drugiej paruzji Jezusa Chrystusa ${ }^{37}$. Również Augustyn w komentarzu o końcu świata, naucza o pierwszym i drugim przyjściu Chrystusa $^{38}$. Ewangelie i Dzieje Apostolskie wyraźnie świadczą o powtórnym przyjściu Chrystusa (Mt 24, 23-31; Mk 13, 24-27; Łk 18, 8; Łk 21, 25-28; Dz $1,11)$. W Dziejach Apostolskich znajdujemy moralną zachętę do pokuty i nawrócenia przed powtórnym przyjściem Mesjasza:

„Pokutujcie więc i nawróćcie się, aby grzechy wasze zostały zgładzone, aby nadeszły od Pana dni ochłody, aby też posłał wam zapowiedzianego Mesjasza, Jezusa, którego niebo musi zatrzymać aż do czasu odnowienia wszystkich rzeczy, co do wieków przepowiedział Bóg przez usta swoich świętych proroków" (Dz 3, 19-21).

Jak należy rozumieć „,czas odnowienia wszystkich rzeczy”, czy dotyczy on zapowiedzianych „kataklizmów ziemskich”, czy „katastrof kosmicznych”, poprzedzających powtórne przyjście Mesjasza? Starożytna szkoła egzegetyczna w Aleksandrii (Klemens Aleksandryjski, Orygenes) dopatrywała się w grec-

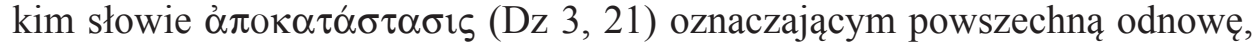
powszechne pojednanie, powszechne zbawienie, sugestii, że kary piekielne podlegają czasowym ograniczeniom ${ }^{39}$. Teoria ostatecznej odnowy wszechrzeczy i powrotu do stanu doskonałej szczęśliwości na końcu czasów została jednak odrzucona przez magisterium Kościoła ${ }^{40}$. Pozostaje faktem, że czasy przedostatnie, inaczej mówiąc czasy mesjańskie dotyczące epoki od wniebowstąpienia do paruzji, charakteryzują się - według wypowiedzi Piotra - nadzieją na powszechne pojednanie ludzkości z Bogiem. Zasadnicze pytanie dotyczy znaków, jakie poprzedzać będą wielokrotnie wspominane w Ewangelii powtórne przybycie Chrystusa. Według Ojców greckich będzie nim albo sam Chrystus albo krzyż „znak Syna Człowieczego” (Mt 24, 30). Według tradycji judeo-chrześcijańskiej powtórne przyjście Chrystusa zostanie poprzedzone przyjściem Eliasza (por. Ml 3, 23-24; Mk 9, 12) . $^{4}$.

W Dziejach Apostolskich zawarty jest bardzo istotny dialog apostołów z Chrystusem poprzedzający wniebowstąpienie. „«Panie, czy w tym czasie przywrócisz królestwo Izraela?» Odpowiedział im: «Nie wasza to rzecz znać

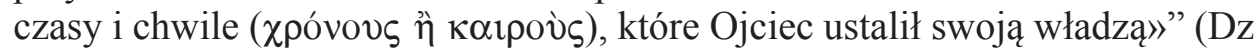
1, 6-7). Kwestia przywrócenia królestwa Narodowi Izraelskiemu była stale w tamtym czasie aktualna, stąd też wielu utożsamiało paruzję z odnową Izra-

${ }^{37}$ Por. Hippolytus, Commentarii in Danielem 4, 18, ed. M. Lefèvre, SCh 14, Paris 2006, 298; tamże 4, 23, SCh 14, 306.

${ }^{38}$ Por. Augustinus, Epistula 199, 2. 6. 17, CSEL 57, 249-250.

${ }^{39} \mathrm{Na}$ temat apokatastazy zob. E.F. Edinger, Archetype of the Apocalypse. A Jungian Study of the Book of Revelation, ed. G.R. Elder, Chicago - La Salle 1999, 169-171.

${ }^{40}$ Por. Concilium Constantinopolitanum II (553), Anathematismi adversus ,tria Capitula” 11.

${ }^{41}$ Por. Augustinus, Tractatus in Joannis Evangelium 4, 5, BAug 71, Paris 1993, 264-265. 
ela ${ }^{42}$. Augustyn w interpretacji tego zdania używa łacińskiego odpowiednika: opportunum tempus oraz tempora aut opportunitates ${ }^{43}$. Wielokrotnie zastanawiano się nad czasem obejmującym okres od wniebowstąpienia do paruzji, Augustyn przytacza teorie mówiące o czterystu latach, pięciuset latach, tysiącu lat ${ }^{44}$. W dziele De civitate Dei biskup Hippony wymienia również liczbę 365 lat pochodzącą z przepowiedni pseudo-apostolskich ${ }^{45}$.

Św. Augustyn w następujący sposób interpretuje „dzień ostateczny” z J 6, 39 :

„Chrystus zmartwychwstał pierwszego dnia tygodnia, my zaś zmartwychwstaniemy w dniu ostatecznym. Pierwszy dzień został zarezerwowany dla Głowy Kościoła, ponieważ prawdziwy nasz dzień to jest Pan nasz Jezus Chrystus, dzień który nie zna zmierzchu. W ostatecznym dniu nastąpi koniec świata. Nie pytajcie się, kiedy nastąpi ten dzień? Dla całego rodzaju ludzkiego jest on jeszcze oddalony, ale jest on bliski każdemu z nas, ponieważ dzień ostateczny jest dniem naszej śmierci" ${ }^{\prime 4}$.

Ambroży z Mediolanu poszukujący sensu moralnego zadał pytanie czemu służy znajomość dnia sądu.

„Czemu służy świadomość tyluż grzechów, jeśli Chrystus przybędzie i nie przyjdzie do mojej duszy? Jeśli Chystus nie żyje we mnie, jeśli Chrystus nie mówi we mnie? To do mnie Chrystus powinien przyjść, to ze względu na mnie powinno mieć miejsce jego przybycie" ${ }^{\wedge 7}$.

Według Ireneusza z Lyonu pisma Starego i Nowego Testamentu ukazują ścisłą łączność pomiędzy śmiercią i grzechem, pomiędzy życiem i sprawiedliwością. Jeszcze dokładniej, śmierć jest oddaleniem od Boga, życie zaś jest przystąpieniem do Boga przez wierność Jego Słowu. Słowo Boże stawia człowieka wobec decydującego wyboru między dobrem i złem, życiem i śmiercią, światłem i ciemnością ${ }^{48}$. Inaczej mówiąc ten wybór dotyczy przyjęcia lub odrzucenia zbawienia obiecanego przez Boga.

\section{DZIEŃ SĄDU}

1. Dies irae. Apokaliptyka żydowska zawiera przepowiednie, które wywarły mocny wpływ na apokaliptykę chrześcijańską, zwłaszcza apokryficzna

${ }^{42}$ Por. Hippolytus, Commentarii in Danielem 4, 16, SCh 14, 292.

${ }^{43}$ Augustinus, Epistula 197, 3, CSEL 57, 233.

${ }^{44}$ Tenże, De civitate Dei XVIII 53, 1, BAug 36, Paris 1960, 678-679.

${ }^{45}$ Tamże XVIII 53-54, BAug 36, 678-689.

${ }^{46}$ Augustinus, Sermo 170, 10, 10, PL 38, 932, thum. własne.

${ }^{47}$ Ambrosius Mediolanensis, Expositio evangelii secundum Lucam X 7, ed. G. Tissot, SCh 52, Paris 1976, 159, tłum. własne.

${ }^{48}$ Por. Irenaeus Lugdunensis, Adversus haereses V 27, 2, ed. A. Rousseau - L. Doutreleau Ch. Mercier, SCh 153, Paris 1969, 342. 
Księga Henocha cytowana w Liście Judy Apostoła (Jud 14-15) ${ }^{49}$. W księgach tych odznaczających się podziałem historii na okresy występują ponadto formuły i symbole charakterystyczne dla pism apokaliptycznych ${ }^{50}$. Jedną z wielu wspólnych tez jest ta, że świat zostanie poddany pod sąd. Kohelet wypowiada się wyraźnie, że w ostatecznym rozrachunku będzie sąd, stąd też używa dwóch określeń „czas i sąd” dotyczących każdej sprawy (Koh 8, 5-6). Opis powszechnego sądu Bożego nad światem spotykamy w tzw. Apokalipsie Izajasza (Iz 24, 1-6), gdzie sąd utożsamiany jest z kataklizmem ,spustoszenia ziemi”, w wyniku którego „przerzedzą się mieszkańcy ziemi i mało ludzi zostało” (Iz 24, 6). Dzień sądu nazywany „dniem nieszczęścia” (Prz 16, 4), czy też dniem gniewu (dies irae), w perspektywie eschatologicznej posiada swój wymiar pedagogiczny. Ostrzeżenie, które znajdujemy na początku Apokalipsy i które stanowi jej zakończenie, mówiące, że „chwila jest bliska” (Ap 1, 3; Ap 22, 10; zob. 1P $4,7)$, posiada również ten sam wymiar. Prorok Jeremiasz w sposób alegoryczny wypowiada się o nieodwołalnym sądzie Pańskim: „I ustanowię przeciw wam cztery rodzaje nieszczęść - wyrocznia Pana: miecz, aby zabijał; psy, by wywlekały; ptaki powietrzne i zwierzęta lądowe, by pożerały i wyniszczyły" (Jr 15, 3). Podobną wypowiedź zanotował św. Jan w Apokalipsie: „Przyszedł dzień wielki gniewu i któż będzie mógł się ostać przed gniewem?” (Ap 6, 17). Temat ira Dei stał się również tytułem filozoficzno-teologicznej monografii pisarza chrześcijańskiego Laktancjusza ${ }^{51}$. Tytuł De ira Dei posiada również Sententia 157 w zbiorze Prospera z Akwitanii, wyjęta z dzieła Augustyna De civitate Dei ${ }^{52}$.

Chrystus rozsyłając Apostołów, aby głosili Ewangelię zapowiada im, że tych, którzy ich nie przyjmą, spotka los gorszy od mieszkańców Sodomy i Gomory (por. Rdz 19, 24-29; Ez 16, 44-58): „Lżej będzie ziemi sodomskiej i gomorskiej w dzień sądu, niż owemu miastu" (Mt 10, 15; 11, 22; 11, 24; 12, 36). W dzień sądu wszystkie czyny człowieka zostaną ujawnione (Rz 2, 16; Mk 4, 22 ; Łk 8, 17; 1Kor 3, 13). Według św. Jana, decyzja o potępieniu lub zbawieniu człowieka zależy od jego wiary w Syna Bożego: „Kto wierzy w Niego, nie podlega potępieniu; a kto nie wierzy już został potępiony, bo nie uwierzył w imię Jednorodzonego Syna Bożego" (J 3, 18). W swoich upomnieniach, uzasadnionych sądem Bożym, św. Piotr zapowiedział: „Czas bowiem, aby sąd się rozpoczął od domu Bożego" (1P 4, 17).

${ }^{49}$ Ed. M. Black: The Book of Enoch, A New English Edition with Commentary and Textual Notes by M. Black, Leiden 1985.

${ }^{50} \mathrm{Na}$ temat ksiąg apokaliptycznych zob. J.J. Collins, The Apocalyptic imagination: An Introduction to the Jewish Matrix of Christianity, Crossroad, New York 1987, 2-8.

${ }^{51}$ Por. Lactantius, De ira Dei, ed. S. Brandt, CSEL 27/1, Pragae - Vindobonae - Lipsiae 1893, 67-132.

${ }^{52}$ Por. Augustinus, De civitate Dei XV 25, BAug 36, 154-155 = Prosper Aquitanus, Liber sententiarum 157, CCL 68A, 293. 
Św. Paweł w Liście do Rzymian dzień sądu nazywa również „dniem gniewu”:

„Oto przez swoją zatwardziałość i serce nieskłonne do nawrócenia skarbisz sobie gniew na dzień gniewu i objawienia się sprawiedliwego sądu Boga, który odda każdemu według jego uczynków (por. Ps 62[61], 13; Hi 34, 11; Syr 16, 15; Jr 17, 10; 32, 19): tym, którzy przez wytrwałość w dobrych uczynkach szukają chwały, czci i nieśmiertelności - życie wieczne; tym zaś, którzy są przekorni, za prawdą pójść nie chcą, a oddają się nieprawości - gniew i oburzenie" (Rz 2, 5-8).

Księgi biblijne, zwłaszcza autorstwa św. Jana, ukazują sąd Boży w sposób koherentny, jako „duchową walkę” (por. 1Tm 1, 18) szatana z Duchem Świętym o człowieka. Przed trybunałem Boga, szatan pełni funkcję oskarżyciela (accusator noster ${ }^{53}$ ), na co znajdujemy świadectwo w Apokalipsie:

„I słyszałem głos donośny w niebie mówiący: Teraz nastało zbawienie i moc i królestwo Boga naszego i władza Chrystusa jego, gdyż zrzucony został oskarżyciel braci naszych, który ich oskarżał przed obliczem Boga naszego we dnie i w nocy" (Ap 12, 10).

Dlatego też w Ewangelii św. Łukasza czytamy:

„A Bóg, czyż nie weźmie w obronę swoich wybranych, którzy dniem i nocą wołają do Niego, i czy będzie zwlekał w ich sprawie?" (Łk 18, 7).

Te wypowiedzi świadczą o koherencji tekstów biblijnych, zwłaszcza, że autorem Dziejów Apostolskich jest ten sam autor co i Ewangelii. Tak jak szatan jest oskarżycielem człowieka „we dnie i w nocy”, czyli stale oskarżającym, tak też Duch Święty od czasu Pięćdziesiątnicy pełni funkcję adwo-

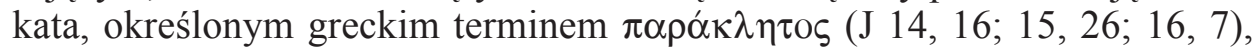
funkcję obrońcy, rzecznika, protektora przed tronem Bożym, którego sens jest o wiele głębszy niż sens słowa łacińskiego „Pocieszyciel” (Dz 9, 31). To tłumaczenie $\mathrm{z}$ języka łacińskiego na języki nowożytne osłabiło sens terminu greckiego, który oznacza tego, który został wezwany, aby przybyć z pomocą. Paraklet jest bowiem adwokatem, który stale asystuje i radzi. Beatus z Liébana dokonał podsumowania zasadniczo dwóch różnych zdań dotyczących „Parakleta”:

„«Paraclitus» dicitur, eo quod nos in tribulatione consolat. «Paraclisis» enim graece, latine «consolatio» dicitur. Alii paraclitum latine «oratorem» uel «aduocatum» interpretantur noster" ${ }^{\natural 4}$.

${ }^{53}$ Por. Beatus Liebanensis, Commentarius in Apocalypsin VI, ed. E. Romero-Pose: Sancti Beati a Liebana Commentarius in Apocalypsin, Scriptores Graeci et Latini Consilio Academiae Lyncorum Editi, II, Romae 1985, 113-114.

${ }^{54}$ Tamże XII, ed. Romero-Pose, II, s. 384. 
Tak też widzimy, że kwestia Ducha Świętego i sposobu jego interpretacji była aktualna w średniowiecznej dualistycznej eschatologii.

Wczesnochrześcijański pisarz Orygenes zauważył, że Duch Święty jest Parakletem, ale także Chrystus jest Parakletem jako Pośrednik (por. 1J 2, 1$)^{55}$. Podobną wypowiedź znajdujemy u Augustyna, który również uważa, że łacińskim odpowiednikiem greckiego terminu „Paraklet” jest „adwokat”56. Termin ten stosowano w literaturze rabinistycznej na określenie obrońcy człowieka przed trybunałem Boga. W 2. poł. IV w. Dydym z Aleksandrii, w tym samym sensie, wypowiedział się o roli Ducha Świętego ${ }^{57}$. Według Dydyma, Duch Święty pełni funkcję „legata” przed Bogiem Ojcem ${ }^{58}$. Eschatologiczna wizja sądu ostatecznego przed trybunałem Bożym, gdzie rolę oskarżyciela spełnia szatan, a funkcję adwokata Duch Święty, podkreśla dualizm dobra i zła w człowieku, a zarazem wskazuje na jego ostateczne przyczyny. W pismach mądrościowych Starego Testamentu znajdujemy stwierdzenie, że „Korzeniem zamierzeń jest serce, skąd wyrastają cztery gałęzie: dobro i zło, życie i śmierć” (Syr 37, 17-18). Pojawiająca się kwestia zła i związanego z nim szatana określonego przez Laktancjusza jako machinator omnium malorum ${ }^{59}$, oraz Ducha Świętego uświęciciela człowieka stanowi argument za tym, że wszelkie dobro pochodzi od Boga. To właśnie Duch Święty ,przekona świat o grzechu, o sprawiedliwości i o sądzie" (J 16,8). O grzechu ponieważ, świat nie wierzy w Chrystusa, o sprawiedliwości ponieważ Chrystus odszedł do Ojca, o sądzie zaś dlatego bo „władca tego świata [już] został osądzony” (J 16, 10-11).

W Księdze Daniela czytamy słowa skierowane do niego: „Ty jednak, Danielu, ukryj słowa i zapieczętuj księgę aż do czasów ostatecznych" (Dn 12, 4; Ez 2, 8 - 3, 3). Proroctwo mówi o „okresie ucisku”, czyli prześladowaniu oraz o zbawieniu wszystkich tych, których imiona zostały zapisane w księdze (por. Dn 12,1). Ta księga została określona w Apokalipsie jako „księga życia zabitego Baranka" (Ap 13, 8; 21, 27; por. Flp 4, 3; Ap 3, 5; 17, 8; 20, 12. 15; $22,19)$, w której zapisane zostały imiona tych wszystkich, którzy nie oddali pokłonu „,bestii”, na której siedmiu głowach były umieszczone ,imiona bluźniercze" (Ap 13, 1) w postaci tytułów boskich (dominus ac deus) cesarzy pogańskiego Rzymu ${ }^{60}$. Tą „księgą życia” jest sam Chrystus sprawiedliwy sędzia „który odda każdemu według uczynków jego” (Rz 2, 6. 16) ${ }^{61}$. Ponadto Apo-

${ }^{55}$ Por. Origenes, De principiis II 7, 4, ed. H. Crouzel - M. Simonetti, SCh 252, Paris 1978, 332-334.

${ }^{56}$ Augustinus, Tractatus in Joannis Evangelium 74, 4, ed. M.-F. Berrouard, BAug 74A, Paris 1993, 326-327.

${ }^{57}$ Por. Didymus Alexandrinus, De Spiritu Sancto 120, ed. L. Doutreleau, SCh 386, Paris 1992, 256.

${ }^{58}$ Por. tamże 122, SCh 386, 258.

${ }^{59}$ Lactantius, Divinae institutiones VII 24, ed. S. Brandt, CSEL 19, Pragae - Vindobonae Lipsiae 1980, 659.

${ }^{60}$ Por. Beatus Liebanensis, Commentarius in Apocalypsin VI, ed. ed. Romero-Pose, II, s. 122161 i 164; IX, ed. Romero-Pose, II, s. 281-285.

${ }^{61}$ Por. tamże XII, ed. Romero-Pose, II, s. 373. 
kalipsa ukazuje liturgię otwierania zapieczętowanej księgi (signatum librum) przeznaczeń przez Baranka (Ap 5, 1 - 6, 17), ponieważ On, według Grzegorza Wielkiego, odsłoni wszystkie tajemnice dotyczące Jego męki i zmartwychwstania ${ }^{62}$. Zbawieni więc będą mieć pełny udział w zmartwychwstaniu Chrystusa. Otwieraniu księgi zapieczętowanej siedmioma pieczęciami przez Baranka towarzyszy siedem wizji. Po otwarciu siedmiu pieczęci następuje wizja siedmiu trąb, którym towarzyszą plagi i katastrofy. Kolejno następujące po sobie wizje zapowiadają prześladowanie, sąd Boży i zbawienie stanowiące wielki finał eschatologicznego dramatu. Powszechne zmartwychwstanie i sąd

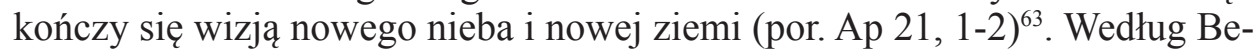
atusa z Liébana wizja „nowego nieba” dotyczy Kościoła rozumianego jako Ciało Chrystusa, nie tylko w jego wymiarze eschatologicznym, ale również doczesnym ${ }^{64}$.

„W szyscy bowiem musimy stanąć przed trybunałem Chrystusa, aby każdy otrzymał zapłatę za uczynki dokonane w ciele, złe lub dobre" (2Kor 5, 10). Apokaliptyczna wizja sądu Bożego sprawi, że w średniowieczu pojawi się nowy temat, medytacja nad własną śmiercią, rozumianą jako dialog człowieka ze swoją własną duszą, oddzieloną przez śmierć. Za przykład może służyć $D e$ meditatione mortis Ruperta $\mathrm{z}$ Deutz ${ }^{65}$. W pismach tych powszechnie przytaczano w formie parafrazy słowa Psalmu: „Miarą naszych lat jest lat siedemdziesiąt lub, gdy jesteśmy mocni, osiemdziesiąt; a większość z nich to trud i marność: bo szybko mijają, my zaś odchodzimy" (Ps 90[89], 10). Teksty biblijne stanowiły podstawę do rozważań nad śmiercią w formie upomnienia: „pamiętaj o swym kresie” (Syr 7, 36) lub w formie modlitwy: „Panie pozwól mi poznać mój kres” (Ps 39[38], 5). Nauczanie Kościoła stale przypominające o śmierci (memento mori) ukazuje transcendentne przeznaczenie człowieka, a nie tylko unicestwienie ludzkiego, materialnego bytu związanego z cierpieniem i śmiercią ${ }^{66}$.

\section{WIELKIE PRZEŚLADOWANIE}

Wśród biblijnych wydarzeń eschatologicznych wymienione jest wielkie prześladowanie dotyczące całego Kościoła. Poprzedzone ono zostało w Ewangelii zapowiedzią zniszczenia świątyni w Jerozolimie i jako takie właśnie stanowi istotną treść eschatologicznego nauczania Chrystusa. Dostrzegając, że system religijny upada prowadząc naród do katastrofy, Jezus ogłasza zburzenie świątyni. Pytanie uczniów skierowane do Niego stale jest ponawiane w każdych czasach: „Powiedz nam, kiedy to nastąpi i jaki będzie

\footnotetext{
${ }^{62}$ Gregorius Magnus, Homiliae in Hiezechielem prophetam II 4, 19, SCh 360, 220.

${ }^{63}$ Por. Collins, The Apocalyptic imagination, s. 212.

${ }^{64}$ Por. Beatus Liebanensis, Commentarius in Apocalypsin XII, ed. Romero-Pose, II, s. 380-381.

${ }^{65}$ Por. Rupertus Tuitiensis, De meditatione mortis libri I-II, PL 170, 357-390.

${ }^{66}$ Por. Tillich, Systematic Theology, III/5: History and the Kingdom of God, s. 396.
} 
znak Twego przyjścia i końca świata?” (Mt 24, 3) Augustyn udziela zaś filozoficznej odpowiedzi: „Im bardziej świat postępuje w wieku, tym bardziej zbliża się do swego końca" ${ }^{67}$. Wersja Mateusza różni się od pozostałych wersji większą precyzją, wersje zaś Łukasza i Marka są bardziej zbieżne. „Nauczycielu, kiedy to nastąpi? I jaki będzie znak, gdy się to dziać zacznie?" (Łk 21, 7; por. Mk 13, 4). Św. Augustyn w dziele O państwie Bożym przytacza teorię o dziesięciu prześladowaniach starożytnego Kościoła ${ }^{68}$. Wszelkie prześladowanie chrześcijan, zwłaszcza według określenia św. Pawła: „z powodu krzyża Chrystusowego" (Ga 6, 12), przynosiło Kościołowi pozytywny skutek, śmierć męczeńska bowiem była i jest uwolnieniem spod władzy zła, a zarazem świadectwem złożonym dla całego Kościoła. Prześladowanie bowiem uprzywilejowało głoszenie Ewangelii, według tezy Tertuliana „nasieniem jest krew chrześcijan (semen est sanguis christianorum)" "Stąd też u początków chrześcijańskiej teologii zdaniem Ernesta Käsemann'a jest theologia viatorum i theologia crucis $^{70}$. W 2. poł. VIII w. Ambroży Autpert w Komentarzu do Apokalipsy poruszając problem powszechnego prześladowania mówi o dwóch społecznościach: „społeczności Baranka” (civitas Agni) i „społeczności Bestii" (civitas bestiae) ${ }^{71}$. Postacie apokaliptyczne Baranek i Bestia pozostające w całkowitej opozycji do siebie dały początek tym dwóm społecznościom. To prześladowanie dotyczyć będzie wszystkich narodów, ponieważ „społeczność Bestii” przebywa w każdym narodzie zwiedzionym przez szatana. Ta dualistyczna wizja świata podzielonego na dwie społeczności zwane populus Dei oraz populus diaboli pojawia się $\mathrm{w}$ tym samym czasie w dziele hiszpańskiego teologa Beatusa z Liébana ${ }^{72}$.

1. Quando haec erunt? Jaka odległość dzieli wizję i zapowiedź od realizacji tych wydarzeń w konkretnym czasie? Chrystus w mowie eschatologicznej zapowiedział zburzenie świątyni jerozolimskiej, swoje powtórne przyjście i prześladowanie uczniów (por. Mt 24, 1-3; Mk 13, 1-4; Łk 21, 5-7. 20). Wypowiedzi Chrystusa zawarte w Ewangelii (por. Mt 24, 21) wyraźnie świadczą o „wielkim prześladowaniu” lub „wielkim ucisku chrześcijan”: „Albowiem dni owe będą czasem ucisku, jakiego nie było od początku stworzenia Bożego aż dotąd i nigdy nie będzie" (Mk 13, 19; Mt 24, 21; por. Dn 12, 1). Mateusz i Marek wyraźnie nawiązują do wizji Daniela. Rodzi się pytanie kiedy nastanie straszliwy ucisk? „Lecz o owym dniu i godzinie nikt nie wie, ani aniołowie

${ }^{67}$ Augustinus, Sermo 296, 7, 8, PL 38, 1356.

${ }^{68}$ Tenże, De civitate Dei XVIII 52, BAug 36, 672-673.

${ }^{69}$ Tertullianus, Apologeticum 50, 13, ed. E. Dekkers, CCL 1, Turnholti 1954, 171.

${ }^{70}$ E. Käsemann, The Beginning of Christian Theology, w: Apocalypticism, ed. R.W. Funk, Journal for Theology and the Church 6, New York 1969, 17-46.

${ }^{71}$ Ambrosius Autpertus, Expositio in Apocalypsin IX 20, 7, ed. R. Weber, CCCM 27A, Turnhout $1975,758$.

${ }^{72}$ Beatus Liebanensis, Commentarius in Apocalypsin X, ed. Romero-Pose, II, s. 306 i 317; XI, ed. Romero-Pose, II, s. 337. 
w niebie, ani Syn tylko sam Ojciec" (Mk 13, 32, por. Mt 24, 36) ${ }^{73}$. Zapowiedź ta jest zachętą do czujności, która stale powraca na kartach Ewangelii (Mt 24, 42. 50; 25, 13; 1Tes 5, 4; Jud 6). Stąd też Augustyn zachęcał chrześcijan do oczekiwania przyjścia Chrystusa ze szczerą wiarą i wytrwałą nadzieją, wypełniając przykazanie miłości ${ }^{74}$. Według Augustyna, dzień powtórnego przyjścia Chrystusa może być zaliczony do „tajemnic Syna” jako „syna Dawida” (filius David: Mt 1, 1; 9, 27; 12, 23; 15, 22; 20, 30. 31; 21, 9. 15; Mk 10, 47. $48 ; 12,35-37$; Łk 18, 38. 39; 20, 41-44; Rz 1, 3; 2Tm 2, 8), czyli Boga przychodzącego $\mathrm{w}$ pełnym człowieczeństwie. W tajemnicy powtórnego przyjścia Chrystusa ukryta jest pewna pedagogia Boża, zmierzająca do tego, aby człowiek był stale moralnie przygotowany na Jego przyjście. Lecz jeśli Chrystus nauczyciel człowieka oznajmił, że On sam nie wie kiedy ten dzień nastąpi, to tylko dlatego, że nie było to w Jego misji, aby człowiekowi o tym powiedzieć. W rzeczywistości Ojciec nie wie nic więcej, czego by Syn nie znał, ponieważ wiedza Ojca jest mądrością, a mądrością Bożą jest Syn lub Jego Słowo. Dlatego też Chrystus nauczał człowieka jedynie to co dla niego jest pożyteczne. W tym sensie należy rozumieć słowa, że Syn nie wie tego czego nie naucza, lub w innych słowach nie zna tego, czego człowiekowi nie objawił ${ }^{75}$.

Augustyn spośród profetycznych znaków przyszłych wydarzeń wyróżnia trzy zawarte w Ewangelii: ruiny Jerozolimy; pierwsze przyjście Chrystusa w Ciele, którym jest Kościół; drugie przyjście Chrystusa jako Głowa Kościoła. Według Augustyna należy dokładnie przeanalizować tę wypowiedź, aby tego, co dotyczy w sensie profetycznym zburzenia Jerozolimy, nie odnieść do końca świata, a tego zaś, co dotyczy końca świata nie zastosować do zburzenia Jerozolimy, przy jednoczesnym rozróżnieniu przyjścia Chrystusa w Ciele, dotyczącym Kościoła, od przyjścia Chrystusa jako Głowy Kościoła ${ }^{76}$. W Ewangelii zburzenie świątyni jest znakiem zniszczenia świata w dniu sądu, a także symbolicznym upadkiem religijności. Ambroży z Mediolanu opisał również znaki towarzyszące schyłkowi świata jako choroby tego świata, do których zaliczają się: głód (fames), choroba trądu (pestilentia), prześladowania (persecutio $)^{77}$. W sensie alegorycznym ,ruiny Jerozolimy” oznaczają upadek żydowskiej synagogi i narodziny Kościoła, ale jednocześnie wewnętrzną świątynię człowieka, która ginie, jeśli jego wiara zanika $(1 \mathrm{Tm} 1,19)^{78}$.

Jaka powinna być postawa chrześcijan względem świata, rozumianego w sensie materialnym? Na to pytanie Ewangelia według św. Jana udziela od-

${ }^{73}$ Por. Origenes, Commentarii in Matthaeum (Mt 24, 36) 55, ed. E. Klostermann - U. Treu, GCS 38, Berlin 1976, 124-128; Augustinus, Enarrationes in Ps. 6, 1, CCL 38, 27.

${ }^{74}$ Augustinus, Epistula 199, 4. 15, CSEL 57, 255-256.

${ }^{75}$ Tenże, Enarrationes in Ps. 36(1), 1, CCL 38, 336.

${ }^{76}$ Por. tenże, Epistula 199, 9. 26, CSEL 57, 266. Zob. E. Lamirande, Reliquit et matrem synagogam. La Synagogue et l'Église selon Saint Augustin, „Collectanea Augustiniana” 41 (1991) 677-688.

${ }^{77}$ Ambrosius Mediolanensis, Expositio evangelii secundum Lucam X 10, SCh 52, 160.

${ }^{78}$ Tamże X 6, SCh 52, 158. Podobna wypowiedź znajduje się u Beatusa z Liébana (Commentarius in Apocalypsin VI, ed. Romero-Pose, II, s. 178). 
powiedzi: „Jeżeli was świat nienawidzi, wiedzcie, że Mnie pierwej znienawidził" (J 15, 18). Całe życie Chrystusa było naznaczone prześladowaniem. Również prześladowanie to dotknie Jego uczniów (por. Mt 24, 9-10). Chrystus zaświadczył, że świat żyje w grzechu (por. J 7, 7). Ponieważ Chrystus „zwyciężył świat” (J 16, 33), chrześcijanie są również wezwani aby być „zwycięzcami świata”, „a kto zwycięża świat, jesli nie ten, kto wierzy, że Jezus jest Synem Bożym?” (1J 5, 5). Augustyn zastanawia się w tym kontekście rozumienia świata nad tym, co powinien uczynić chrześcijanin? I odpowiada: „korzystać ze świata, a nie służyć światu. Posiadać tak jakby nie posiadając”79. W tej wypowiedzi uwidacznia się egzystencjalna kwestia być i mieć.

Kościół ze swej strony dozna ostatecznej próby, zanim powtórnie przybędzie Chrystus. Zapanuje tzw. misterium niegodziwości, prześladowanie, odejście od praktyk religijnych, idolatria, wyrzeczenie się wiary, czyli apostazja. Nastąpi tzw. pseudo-mesjanizm, w którym człowiek zajmie miejsce Boga, Mesjasza, który przybył jako człowiek na ziemię. Św. Jan w przesłaniu do Kościoła w Filadelfii napisał słowa pełne nadziei: „Skoro zachowałeś nakazy mojej wytrwałości i Ja cię zachowam od próby, która ma nadejść na cały obszar zamieszkany, by wypróbować mieszkańców ziemi” (Ap 3,10).

„W owym dniu uczynię Jeruzalem ciężkim głazem dla wszystkich ludów. Każdy, kto go spróbuje podnieść, dotkliwie się pokaleczy. Wszystkie narody się zgromadzą przeciw niemu" (Za 12, 3). Zdobywanie mądrości ukazane jest w Piśmie przy pomocy metafory „kamienia próby”. Był to duży, okrągły kamień, którym młodzież przez podnoszenie próbowała swych sił. „Jak potężny kamień próby go przytłoczy i nie będzie zwlekał z jej odrzuceniem" (Syr 6, 21).

Ucisk i prześladowanie są to znaki nadchodzącego dnia sądu (por. 1P 4, 17; 1Tes 3, 3-5). Na przykładzie dziejów Izraela św. Paweł wyjaśnia: „A wszystko to przydarzyło się im jako zapowiedź rzeczy przyszłych, spisane zaś zostało ku pouczeniu nas, których dosięga kres czasów" (1Kor 10,11). I dalej pełen optymizmu podaje: „Pokusa nie nawiedziła was większa od tej, która zwykła nawiedzać ludzi. Wierny jest Bóg i nie dozwoli was kusić ponad to, co potraficie znieść, lecz zsyłając pokusę, równocześnie wskaże sposób jej pokonania, abyście mogli przetrwać" (1Kor 10,13).

\section{APOKALIPTYCZNE SYMBOLE LICZBOWE: „CZTERDZIEŚCI DWA MIESIĄCE” (CZASY POGAN)}

Apokaliptyczne symbole liczbowe noszą w sobie ślady religii Wschodu oraz filozofii greckiej. Połączenie tych dwóch rzeczywistości zapoczątkowało gnostycyzm, który odziedziczył przekonanie o całkowitym dualizmie między Bogiem i światem, między duszą i ciałem, dobrem i złem. Filozofia grecka nadała gnostycyzmowi element spekulatywny. Stąd też rozważania dotyczące pośrednictwa między Bogiem i światem znajdujemy na przykład w filozofii

\footnotetext{
${ }^{79}$ Augustinus, Enarrationes in Ps. 95, 14, CCL 39, 1352, thum. własne.
} 
neoplatońskiej. Elementy „tajemnej wiedzy” weszły do literatury biblijnej jako apokaliptyczne symbole liczbowe, zwłaszcza od czasu podbojów Wschodu przez Aleksandra Wielkiego w IV w. prz. Chr. Wizja świata ukazana w biblijnej literaturze apokaliptycznej bazuje na dualizmie pochodzącym z gnostycyzmu, umieszczając między Bogiem i człowiekiem szatana. Okres działalności szatana w Piśmie Świętym został nazwany „czasem pogan”, dotyczącym domeny teologicznej i moralnej. Pogaństwo bowiem związane zawsze było $\mathrm{z}$ idolatrią, a także z postępowaniem sprzecznym z zasadami etyki i moralności biblijnej. W planie Bożym, według biblijnej literatury apokaliptycznej, to właśnie poganie zajmą miejsce Żydów (por. Łk 20, 16): „A Jerozolima będzie deptana przez pogan, aż czasy pogan przeminą" (Łk 21, 24). Przedziwny zbieg okoliczności zachodzi między fragmentem z Ewangelii według Łukasza i Apokalipsą, gdzie czytamy: „Wstań i zmierz Świątynię Bożą i ołtarz, i tych, co wielbią w niej Boga. Dziedziniec zewnętrzny Swiątyni pomiń zupełnie i nie mierz go, bo został dany poganom, i będą deptać Miasto Święte czterdzieści dwa miesiące” (Ap 11,1-2). Ten temat „mierzenia miasta” powraca pod koniec Apokalipsy, gdzie opisane zostało Jeruzalem czasów mesjańskich (por. Ap 21, 15-17) z wyjaśnieniem, że „miara, którą miał anioł, jest miara człowieka”. Grzegorz Wielki w homilii do Ezechiela napisał: „Mensura hominis quae est angeli" ${ }^{\prime 0}$, co oznacza, że miarą człowieka jest miara anioła, w tym sensie, że ludzie zostaną doprowadzeni aż do zrównania $\mathrm{z}$ aniołami (por. Mt 22, 30). Co oznacza zwrot „zmierz Świątynię Bożą’? Czy nie występuje tu analogia do wydarzeń z czasów zapowiedzianych przez proroka Ezechiela (Ez 5, 1-17), kiedy ludy pogańskie najechały na Jerozolimę i zbezcześciły jej święte miejsca, deportując ludność do Babilonii? Czy chodzi tutaj, w kontekście tzw. „teologii katastrofy”, o ocalenie Świątyni Bożej przed zburzeniem? Czterdzieści dwa miesiące (por. Ap 13,5) jest to okres trzech i pół roku (por. Ap 11,9), co odpowiada tysiącu dwustu sześćdziesięciu dniom wymienionym w Apokalipsie 12, 6. Ten zaś okres został zidentyfikowany z czasem działalności szatana. W Księdze Daniela spotykamy zaś formułę apokaliptyczną „Do czasu, czasów i połowy [czasu]" (Dn 12, 7), która została również zastosowana w Apokalipsie: „I dano Niewieście dwa skrzydła orła wielkiego, by na pustynię leciała do swojego miejsca, gdzie jest żywiona przez czas i czasy, i połowę czasu, z dala od węża" (Ap 12,14). Wypowiedziane zaś to zostało w kontekście działalności szatana: „Biada ziemi i biada morzu - bo zstąpił na was diabeł, pałając wielkim gniewem, świadom, że mało ma czasu" (Ap 12, 12). W Księdze Mądrości występuje analogiczna formuła, będąca przypuszczalnie wyjaśnieniem logicznym tego enigmatycznego powiedzenia: „Początek i kres, i środek czasów” (Mdr 7, 18). Rozumieć to należy nie tylko jako całość okresu czasu, ale również jako jego skończoność. Tę formułę „do czasu, czasów i połowy czasu" na początku III w. Hipolit zinterpretował jako

${ }^{80}$ Gregorius Magnus, Homiliae in Hiezechielem prophetam II 2, 15, SCh 360, 122. 
dotyczącą trzech i pół roku panowania antychrysta lub tysiąca dwustu dziewięćdziesięciu dni wymienionych u Daniela ${ }^{81}$.

Daniel pisze o okresie tysiąca dwustu dziewięćdziesięciu dni: „A od czasu, gdy zostanie zniesiona codzienna ofiara, zapanuje ohyda ziejąca pustką, [upłynie] tysiąc dwieście dziewięćdziesiąt dni. Szczęśliwy ten, który wytrwa i doczeka tysiąca trzystu trzydziestu pięciu dni” (Dn 12, 11-12). Co oznacza różnica 45 dni $(1290+45=1335)$ ? Na to pytanie starał się udzielić odpowiedzi Hipolit w Komentarzu do Daniela ${ }^{82}$ napisanym w latach wzmożonych prześladowań (202-204). Otóż liczba 1260 dni oznacza okres trzech i pół roku, czas przepowiadania dwóch proroków, prekursorów Mesjasza, Henocha ${ }^{83}$ i Eliasza, liczba zaś 1290 dni - okres antychrysta, w czasie którego po zniszczeniu świątyni jerozolimskiej ,zapanuje ohyda ziejąca pustką” i wielkie prześladowanie chrześcijan, czyli tych którzy nie noszą na ręku znamienia antychrysta (por. Ap 13, 16-17. 18). W czasie 45 dni antychryst usiłował będzie zachować jeszcze swoją władzę. Hipolit mówi również o okresie 50 dni, które są związane z powtórnym przyjściem Chrystusa i definitywnym zakończeniem działalności antychrysta według św. Pawła: „wówczas ukaże się Niegodziwiec, którego Pan Jezus zgładzi tchnieniem swoich ust i wniwecz obróci samym objawieniem swego przyjścia" (2Tes 2,8$)$. Podobna interpretacja znajduje się w komentarzu do Apokalipsy Beatusa z Liébana ${ }^{84}$.

Okres czasu, wynoszący trzy i pół roku, wspomniany jest również w Ewangelii według św. Łukasza w związku z prorokiem Eliaszem, który został posłany do wdowy w Sarepcie Sydońskiej w okresie suszy, ponieważ „niebo pozostawało zamknięte przez trzy lata i sześć miesięcy, tak że wielki głód panował w całym kraju" (Łk 4, 25; Jk 5, 17; por. $1 \mathrm{Krl} \mathrm{17,} \mathrm{1-24;} 1 \mathrm{Krl} 18,2$ ). Hieronim ze Strydonu w Komentarzu do Daniela podaje, że okres panowania antychrysta wynosić będzie trzy i pół roku, co odpowiada tysiącu dwustu dziewięćdziesięciu dniom zbezczeszczenia świątyni w Jerozolimie stanowiącej centrum religii żydowskiej ${ }^{85}$. Podobna interpretacja tych apokaliptycznych symboli liczbowych znajduje się w komentarzu do Apokalipsy Beatusa z Liébana. Beatus odnotował, że okres trzech lat i sześciu miesięcy jest równoznaczny z okresem czterdziestu dwóch miesięcy ${ }^{86}$.

Czas pogan to nie tylko czas działalności szatana, ale przede wszystkim to czas, w którym nastąpi zapowiedziany upadek świątyni (por. Am 9, 1-4). Wydarzenia historyczne dotyczące zbezczeszczenia świątyni Salomona (1Krl

${ }^{81}$ Por. Hippolytus, Commentarii in Danielem 4, 14, SCh 14, 290; tamże 4, 57, SCh 14, 378-380.

${ }^{82}$ Por. tamże 4, 50-55, SCh 14, 366-374.

${ }^{83}$ Siódmy po Adamie patriarcha Henoch (Rdz 4, 17-18; 5, 18-24; 46, 9; Wj 6, 14; Lb 26, 5; $1 \mathrm{Krn} \mathrm{1,} \mathrm{3;} \mathrm{5,} \mathrm{3;} \mathrm{Syr} \mathrm{44,} \mathrm{16;} \mathrm{49,} \mathrm{14;} \mathrm{Łk} \mathrm{3,} \mathrm{37;} \mathrm{Hbr} \mathrm{11,} \mathrm{5;} \mathrm{Jud} \mathrm{14-15).}$

${ }^{84}$ Por. Beatus Liebanensis, Commentarius in Apocalypsin XI, ed. Romero-Pose, II, s. 364-365.

${ }^{85}$ Por. Hieronymus Stridonensis, De Antichristo in Danielem IV 7a, ed. F. Glorie, CCL 75A, Turnhout 1964, 941; tamże IV 11, CCL 75A, 942-943.

${ }^{86}$ Por. Beatus Liebanensis, Commentarius in Apocalypsin V, ed. Romero-Pose, II, 67-69. 
5, $15-6,38 ; 2 \mathrm{Krn} 2-6)$ przez pogan w 169 r. prz. Chr., kiedy Antioch IV Epifanes po profanacji obrabowat ją (por. 1Mch 1, 20-28) i kiedy na ołtarzu całopalenia wybudował w roku 167 ,ohydę spustoszenia” (1Mch 1, 54), ołtarz Jowisza Olimpijskiego (posąg Zeusa) (2Mch 6, 2), trwały trzy lata aż do czasu oczyszczenia świątyni w 164 r. (por. 1Mch 4, 36-61; 2Mch 10, 1-8). Przez trzy lata świątynia była „deptana przez pogan”. Hipolit jednak wyraźnie mówi o czasie trzech i pół roku lub o tysiącu trzystu dniach, kiedy to pojawił się Juda Machabeusz i zdobył świątynię i miasto ${ }^{87}$. Na pamiątkę poświęcenia ołtarza ustanowiono święto Chanukka, w czasie którego Żydzi palą wiele światła. Posąg Zeusa i zbezczeszczenie świątyni pozostały u Żydów na zawsze symbolem ohydy i odrazy (por. Dn 9, 27; 11, 31; 12, 11; Mt 24, 15; Mk 13, 14; $Ł k 21,20$ ), który łączono ze zdarzeniami eschatologicznymi i końcem świata. Chrystus powoła się na ten werset w mowie eschatologicznej zapowiadając zburzenie świątyni i koniec świata (por. Mt 24, 15). Augustyn w De civitate Dei wspomina, że po powrocie z niewoli odbudowano świątynię, lecz Pompejusz (106-148), jeden z przywódców Narodu Rzymskiego (pierwszy triumwirat) zawładnął Judeą i wszedł do świątyni nie jako adorator, ale profanator:

„Pompeius ergo, populi Romani praeclarissimus princeps, Iudaeam cum exercitu ingressus civitatem capit, templum reserat, non devotione supplicis, sed iure victoris, et ad sancta sanctorum, quo nisi summum sacerdotem non licebat intrare, non ut venerator, sed ut profanator accedit" $" 88$.

W czasach Nerona (66) wybuchnie powstanie żydowskie, wypełnione tragicznymi epizodami, o których opowiada Józef Flawiusz. Oblężenie przez Tytusa (IV-VIII 70) zakończy się zdobyciem miasta i pożarem świątyni.

Nawiązując do siedemdziesięciu lat z Księgi Jeremiasza (Jr 25, 11-12) dotyczących pobytu Izraela w Babilonie, w następstwie czego spadła kara na Nabuchodonozora, króla Babilonii, Hipolit mówi o enigmatycznym okresie 62 tygodni. Według Hipolita, kiedy dobiegać będzie końca okres 62 tygodni, nastąpi powtórne przyjście Chrystusa poprzedzone w ostatnim tygodniu pojawieniem się Eliasza i Henocha, a także działalnością antychrysta określoną jako „ohyda spustoszenia" ${ }^{\prime}$.

Autor Listu do Rzymian $(11,25)$ pisze o całkowitym nawróceniu i wejściu do Kościoła „pełni pogan”, stąd też nie tylko Izrael, ale i poganie doświadczą miłosierdzia Bożego. Retorycznym zawołaniem „O głębokości bogactw, mądrości i wiedzy Boga!”, przypominającym określenia znane z apokaliptyki judaistycznej, Apostoł kończy hymn ułożony na cześć mądrości Bożej (Rz 11, 25-36). Św. Paweł wyraża przy pomocy zwrotu „pełnia Boża” ( $\pi \lambda \eta \dot{\eta} \omega \mu \alpha$, por. Ef 1,$23 ; 3,19)$ osiągnięte przez wszystkich ludzi, Żydów i pogan, nieskończone miłosierdzie Boga. Nawrócenie pogan stanowi jeden z najważniejszych

\footnotetext{
${ }^{87}$ Por. Hippolytus, Commentarii in Danielem 4, 26, SCh 14, 314-316.

${ }^{88}$ Augustinus, De civitate Dei XVIII 45, 3, BAug 36, 648-649.

${ }^{89}$ Hippolytus, Commentarii in Danielem 4, 35, SCh 14, 334.
} 
aspektów zbawienia mesjańskiego w Piśmie Świętym (Iz 45, 14-17; Jr 16, 1921; Mi 4, 1-3), jakim jest jego uniwersalizm.

\section{POSTACI APOKALIPTYCZNE: GOG I MAGOG Z WIZJI EZECHIELA (EZ 38-39) I APOKALIPSY (AP 20, 8)}

Wizja Goga i Magoga stanowi jedną z symbolicznych wizji zawartych w Piśmie Świętym dotyczących czasów ostatecznych. Przepowiednia Ezechiela „Miecz - na zewnątrz, a mór i głód - wewnątrz” (Ez 7, 15) pozostaje bardzo zbieżna z symbolicznymi figurami Goga i Magoga, które to w Piśmie Świętym zawsze występują razem. Te tajemnicze postaci apokaliptyczne noszące tajemnicze imiona stanowiły centrum zainteresowania dla Ojców Kościoła i teologów średniowiecznych w ich pracach dotyczących eschatologii. Eschatologię średniowiecza cechowała bowiem bardzo naturalistyczna wizja dotycząca czasów ostatecznych. Te dwie symboliczne postaci stanowiły obrazową personifikację zła. Według hebrajskiej etymologii ich imion Gog oznacza zło przychodzące z ,zewnątrz” (tectum), Magog zaś zło pochodzące $\mathrm{z}$,wewnątrz” (de tecto). Według Augustyna imiona ich, oznaczajace bądź „dom” bądź tego, kto wychodzi z „domu”, dotyczą narodów w których diabeł był zamknięty i z których wyszedł, a których nienawiść, wcześniej ukryta, stała się jawna ${ }^{90}$. Hieronim zaś w terminie tectum dostrzega twórców herezji, a w wyrażeniu de tecto - ich błędne doktryny ${ }^{91}$. Wizja proroka Ezechiela, dotycząca tajemniczych postaci Goga i Magoga, począwszy od Hieronima cieszyła się licznymi komentarzami szczególnie w okresie wędrówki ludów, w czasie politycznej stabilizacji średniowiecznej Europy oraz w późnym średniowieczu. Hieronim ${ }^{92}$, Ambroży ${ }^{93}$, Augustyn ${ }^{94}$, Quodvultdeus ${ }^{95}$, Teodoret z Cyru ${ }^{96}$, Izydor $^{97}$, Raban Maur ${ }^{98}$, w 2. poł. IX w. Christian ze Stavelot ${ }^{99}$, Ryszard ze św.

${ }^{90}$ Por. Augustinus, De civitate Dei XX 11, BAug 37, 246-247; Beatus Liebanensis, Commentarius in Apocalypsin VIII, ed. Romero-Pose, II, s. 358.

${ }^{91}$ Hieronymus Stridonensis, In Hiezechielem XI 38, ed. F. Glorie, CCL 75, Turnhout 1964, 527.

${ }^{92}$ Por. tenże, Hebraicae quaestiones in Libro Geneseos 10, 21, ed. P. de Lagarde - G. Morin - M. Adriaen, CCL 72, Turnhout 1959, 11; tenże, In Hiezechielem IV 13, CCL 75, 147; tamże XI praef., CCL 75, 480; tamże XI 38, CCL 75, 522-543.

${ }^{93}$ Por. Ambrosius Mediolanensis, De fide ad Gratianum II 16, 138, ed. O. Faller, CSEL 78, Vindobonae 1962, 105.

${ }^{94}$ Por. Augustinus, De civitate Dei XX 11, BAug 37, 246-247.

${ }^{95}$ Por. Quodvultdeus, Liber promissionum et praedictorum Dei IV 4, 5, PL 51, 840.

${ }^{96}$ Por. Theodoretus Cyrensis, Explanatio in Ezechielem 15, 38-39, PG 81, 1199-1220.

${ }^{97}$ Por. Isidorus Hispalensis, Historia de regibus Gothorum, Wandalorum et Suevorum 1, PL 83, 1059.

${ }^{98}$ Por. Rabanus Maurus, Commentaria in Ezechielem XIII 38-39, PL 110, 865-880.

${ }_{99}$ Por. Christianus Stabulensis (Druthmarus), Expositio in Matthaeum Evangelistam 37, PL $106,1405$. 
Wiktora $^{100}$, Joachim z Fiore ${ }^{101}$ zbieżni w swoich komentarzach ukazywali jednak Goga i Magoga na tle konkretnych wydarzeń historycznych. Akomodacja tych symbolicznych postaci do danej rzeczywistości aktualizowała sens profetyczny Biblii. Ogólnie można stwierdzić, że z postaciami tymi kojarzono albo konkretne narody (Rodrigo Jimenes de Rada ${ }^{102}$, abp Toledo w XIII w.), albo terytoria ich zamieszkania (Hugo ze św. Wiktora ${ }^{103}$ ), albo też widziano w nich symbole pogaństwa i związanej z nim idolatrii, a także symbole herezji rozpowszechniających swe błędne doktryny. Gog i Magog stali się symbolem antychrysta, apostazji, tych którzy prześladować będą chrześcijan, wprowadzając tzw. „ohydę ziejącą pustką”. Ich działalność określona zostanie symbolicznym okresem czasu, którego znaczenie zaczną wyolbrzymiać niektórzy fanatyczni zwolennicy, błędnie rozumiejący sens liczb apokaliptycznych. Powszechnie zaś ich imiona związano z przyszłością eschatologiczną (Rupert z Deutz ${ }^{104}$ ).

Św. Jan w Apokalipsie zadawala się stwierdzeniem, że kiedy wypełni się okres tysiąca lat i szatan zostanie uwolniony z uwięzi, pójdzie kusić Goga i Magoga, którzy istnieją ze swymi grzesznymi imionami; natychmiast zgromadzi ich z czterech krańców świata a ich liczba będzie jak piasek morski (quorum numerus est sicut harena maris):

„A gdy się skończy tysiąc lat, szatan będzie zwolniony z więzienia i wyjdzie i będzie zwodził narody, które są na czterech krańcach ziemi Goga i Magoga i zbierze ich na walkę, a ich liczba jest jak piasek morski. I wstąpili na okrąg ziemi (powinno raczej być: cztery krańce ziemi) i otoczyli obóz świętych i miasto umiłowane" (Ap 20, 7-8)"105.

Ezechiel używa imienia Goga, mówiąc o królu, zaś imienia Magoga, mówiąc o kraju, terytorium. Imię Magoga jest wymieniane pośród siedmiu „synów Jafeta", znane z Rdz 10, 2 oraz z 1Krn 1, 5 oznacza syna Jafeta, zamieszkującego prawdopodobnie stepowe zbocza morza Kaspijskiego. Jeśli zaś chodzi o imię Goga, być może jest ono apokopą utworzoną z imienia poprzedniego lub pochodzi z mitologii eschatologicznej asyryjskiej. Gog i Magog stali się

${ }^{100}$ Por. Richardus de Sancto Victore, In visionem Ezechielis 38-39, ed. M.A. Signer, CCCM 53E, Turnhout 1991, 152-155.

${ }^{101}$ Por. Joachim de Flore, Expositio in Apocalypsim 5; ed. Selge, s. 62-65.

${ }^{102}$ Por. Rodericus Ximenius de Rada, Historia de rebus Hispanie siue Historia Gothic I.9, ed. J. Fernandez Valverde, CCCM 72, Turnhout 1987, 22.

${ }^{103}$ Por. Hugo de Sancto Victore, Descriptio mappe mundi 12, ed. P. Gautier Dalché, La „Descriptio Mappe Mundi" de Hugues de Saint-Victor, texte inédit avec introduction et commentaire, Collection des Études Augustiniennes. Serie Moyen-Age et Temps modernes 20, Paris 1988, 145.

${ }^{104}$ Por. Rupertus Tuitiensis, De sancta trinitate et operibus eius XXII, In libros Regum I, ed. H. Haacke, CCCM 22, Turnhout 1972, 1227.

${ }^{105}$ Augustinus, De civitate Dei XX 11, BAug 37, 244-245, thum. własne. Por. Agobardus Lugdunensis, De fidei veritate et totius boni institutione 14, ed. L. Van Acker, CCCM 52, Turnhout 1981, 268; Ambrosius Autpertus, Expositio in Apocalypsin VII 16, 146, CCCM 27A, 619; tamże IX 20, 7, CCCM 27A, 757. 
dwoma narodami. Raban Maur powtarza za Hieronimem ${ }^{106}$, że z imieniem Goga związane są barbarzyńskie ludy Scytii, zamieszkujące ziemie na wschód od Morza Kaspijskiego, siegające aż do Indii (por. Iz 4, 5; $2 \mathrm{Mch} 4$, 47; Kol 3, $11)^{107}$. To one przybędą do ziemi izraelskiej i walczyć będa z Narodem Wybranym $^{108}$. Analogicznie do znaczenia ich imion, Ezechiel przepowiada, że „cudzoziemcy” i „miejscowi złoczyńcy” zagrabią bogactwo Izraela (por. Ez 7, 21). Teodoret z Cyru w Komentarzu do Ezechiela podaje, że „Gog et Magog sunt Scythicae gentes"109, co zgadza się z opisem występującym w dziele Antiquitates Iudaicae Józefa Flawiusza ${ }^{110}$, który podając imiona synów Noego w formie zhellenizowanej wyjaśnia, że synowie Jafeta dali początek ludom, i tak od Gomera wzięli początek Gomarejczycy, nazwani przez Greków Galatami; od Magoga - Magogejczycy, zwani Scytami; od Mada lub Madaja - Madejczycy, zwani Medami; od Jawana - Jonowie i wszyscy Grecy; od Tubala - Iberowie, utożsamiani z ludami zamieszkującymi wschodnią Gruzję lub z ludami zamieszkującymi Półwysep Iberyjski; od Mosocha - Mosocheńczycy, zamieszkujący Kapadocję; od Tyrosa - Tyryjczycy, zwani Trakami.

Zadziwiająca zbieżność zachodzi między dziełem Antiquitates Iudaicae, którego autor widział w potomstwie Noego - Semie, Chamie i Jafecie (por. Rdz 10, 1-6) - początek nowej cywilizacji świata, i pismami Hieronima, w których autor również utożsamia synów Jafeta, Mosocha z mieszkańcami Kapadocji; Tubala z mieszkańcami półwyspu Iberyjskiego, Hiszpanami, lub mieszkańcami Italii; Gomera zaś i jego syna Togarma z mieszkańcami Galacji (miasta Ancyra, Pessynunt, Tavium) i Frygii; potomstwo zaś Chama, Saba i Dadan (synowie Chama, Kusza, Ramy) z Kartagińczykami ${ }^{111}$. Według Flawiusza, Togorma dał początek ludom nazwanym przez Greków Frygami, synowie zaś Chama zamieszkali ziemie od Syrii i Gór Amanu i Libanu aż do Morza Śródziemnego i Oceanu, między innymi od Chusa pochodzą Chusejczycy zwani Etiopami.

Tablica ludów z Księgi Rodzaju mówiąca o pochodzeniu ludzkości popotopowej, zwłaszcza ich nazwy etniczne występujące jako imiona własne protoplastów, jest prototypem eschatologicznym, który znajduje swoją finalizację

${ }^{106}$ Por. Hieronymus Stridonensis, Commentarii ad Isaiam X 27/29, ed. M. Adriaen, CCL 73, Turnhout 1963, 399; tamże X 30/33, CCL 73, 400.

${ }^{107}$ Scytowie, naród zamieszkujący Azję centralną, który według Herodota (zob. Herodotus Historicus, Historiae I 103-106, ed. J. Henderson, LCL 117, Cambridge Mass. 2004, 132-139; tamże II 103, LCL 117, 390-391; tamże II 110, LCL 117, 398-399) najechał na Syrię i Palestynę aż do Egiptu ok. 630 r. prz. Chr., o którym to wspomina być może Izajasz 4, 5.

${ }^{108}$ Por. Rabanus Maurus, Commentaria in Ezechielem XIII 38, PL 110, 867.

${ }^{109}$ Theodoretus Cyrensis, Explanatio in Ezechielem 15, 38 (vers. 1, 2), PG 81, 1199-1200. Por. tamże (vers. 14-16), PG 81, 1205-1206.

${ }^{110}$ Por. Josephus Flavius, Antiquitates Iudaicae I 6, 1-4, ed. E. Warmington, LCL 242, Cambridge Mass. 1967, 58-73, tłum. w: Józef Flawiusz, Dawne dzieje Izraela „Antiquitates Iudaicae”, przekład z języka greckiego pod redakcją Eugeniusza Dąbrowskiego, Poznań 1962, 111-114.

${ }^{111}$ Hieronymus, In Hiezechielem XI 38, CCL 75, 525; XI 38, CCL 75, 527. 
w opisie apokaliptycznym: ,a oto ujrzałem wielki tłum, którego nie mógł nikt policzyć, z każdego narodu i wszystkich pokoleń, ludów i języków, stojący przed tronem i przed Barankiem" (Ap 7,9). Horyzont geograficzny świata znanego dla biblijnego autora rozciągał się od Morza Czarnego na północy do Etiopii na południu, od Medii i Elamu na wschodzie do Grecji i Tarsu w Cylicji na zachodzie. Koncepcja świata według Augustyna również ogranicza się do trzech części: Azji, Europy i Afryki ${ }^{112}$.

Apokalipsa zawiera liczne reminiscencje starotestamentalne między innymi imiona Goga i Magoga z wizji Ezechiela 38-39, Gog przybędzie z północy $(E z 38,15)$ i napadnie na ziemię Izraela ${ }^{113}$. Apokalipsa wspomina również o znakach znanych w starożytnej literaturze apokaliptycznej: „Albowiem są to duchy czartów, które czynią znaki i wychodzą do królów całej ziemi, by ich gromadzić na walkę na dzień wielki wszechmogącego Boga” (Ap 16, 14). Magog zaatakuje Jerozolimę i za to zostanie zniszczony ogniem z nieba. Po tym nastąpi zmartwychwstanie umarłych. Gog i Magog w tradycji żydowskiej reprezentują tych, którzy powstali przeciwko Bogu, stąd też odgrywać będą rolę antychrysta. Zasadniczo jednak imiona Goga i Magoga związane są z idolatrią. Gog, który przybędzie z zewnątrz i Magog, który wyjdzie z wewnątrz w wizji biblijnej ukazani zostali jako nieprzyjaciele eschatologiczni Królestwa Bożego ${ }^{114}$. Hieronim podaje, że wielu uważało, iż barbarzyńscy Goci pochodzą od Goga ${ }^{115}$. Tę hipotezę powtarza Ambroży z Mediolanu ${ }^{116}$; Augustyn zna ją również, lecz ją odrzuca ${ }^{117}$; a następnie Quodvultdeus ${ }^{118}$, Prymazjusz z Hadrumentum ${ }^{119}$ oraz Izydor z Sewilli, twierdząc, że Goci pochodzą z pokolenia Magoga, syna Jafeta ${ }^{120}$, a także Ryszard od św. Wiktora ${ }^{121}$. Ambroży Autpert uważa natomiast, że w tych dwóch imionach - Goga i Magoga - zostały zapisane imiona wszystkich potępionych narodów (reproborum multitudo) ${ }^{122}$.

Po pokonaniu Goga, według wizji Ezechiela (Ez 39), jego żołnierze zostaną pochowani na wschód od Morza Martwego, poza granicami Palestyny:

${ }^{112}$ Augustinus, De civitate Dei XVI 17, BAug 36, 246-249.

113 Por. Hieronymus Stridonensis, In Ioelem prophetam 2, 15-17, ed. M. Adriaen, CCL 76, Turnhout 1969, 185-186; 3, CCL 76, 204; tenże, Epistula 126, 2, CSEL 56/1, Vindobonae - Lipsiae $1910,144$.

${ }^{114}$ Według Hieronima (In Hiezechielem XI 38, CCL 75, 526-527) imiona Goga i Magoga związane są z tymi, którzy odznaczają się pychą i sprzeniewierzyli się prawdzie por. Hieronymus.

${ }_{115}$ Por. Hieronymus Stridonensis, Hebraicae quaestiones in Libro Geneseos 9, 27 - 10, 5, CCL

72, 11; tamże 10, 21, CCL 72, 11; tenże, In Hiezechielem XI 38, CCL 75, 525.

${ }^{116}$ Por. Ambrosius Mediolanensis, De fide ad Gratianum II 16, 138, CSEL 78, 105.

${ }^{117}$ Augustinus, De civitate Dei XX 11, BAug 37, 246-247.

${ }^{118}$ Por. Quodvultdeus, Liber promissionum et praedictorum Dei IV 13, 22, PL 51, 843.

${ }^{119}$ Por. Primasius, Commentarius in Apocalypsin V 20, ed. W. Adams, CCL 92, Turnhout 1985, 279.

${ }^{120}$ Por. Isidorus Hispalensis, Historia de regibus Gothorum, Wandalorum et Suevorum 1, PL 83, 1059.

${ }^{121}$ Por. Richardus de Sancto Victore, In visionem Ezechielis 38, 2, CCCM 53E, 152.

${ }^{122}$ Ambrosius Autpertus, Expositio in Apocalypsin IX 20, 7, CCCM 27A, 758. 
„A przez siedem miesięcy grzebać ich będzie dom Izraela, aby oczyścić ziemię” (Ez 39, 12). „Dolina mnóstwa Goga” stała się miastem zwanym Amona, tj. mnóstwo (Ez 39, 15-16). Podobną wizję ukazuje Apokalipsa: „A dym męki ich wznosić się będzie na wieki wieków i nie mają odpoczynku we dnie i w nocy ci, co się kłaniali bestii i obrazowi jej i jeśli kto przyjął znamię jej imienia" (Ap 14, 11).

\section{BESTIA O DZIESIĘCIU ROGACH I SIEDMIU GŁOWACH Z WIZJI APOKALIPSY (AP 13, 1-18)}

Postać Bestii o dziesięciu rogach i siedmiu głowach (Ap 13,1) w wizji apokaliptycznej oznaczona została liczbą 666 (Ap 13, 18; 15, 2) $)^{123}$. Powszechnie przyjęto tę liczbę na oznaczenie antychrysta; wyraźne utożsamienie Be-

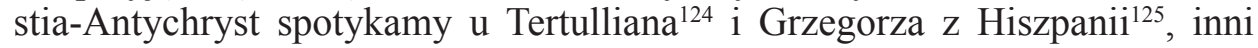
zaś wśród których znajduje się Prymazjusz Z Hadrumentum ${ }^{126}$, Ambroży Autpert $^{127}$ i Bonawentura przytaczają określenie Ireneusza $\mathrm{z}$ Lyonu, które bardziej uwydatnia liczbę imienia antychrysta (numerus nominis), reprezentującą symboliczny czas jego panowania ${ }^{128}$. Ireneusz z Lyonu uważa, że liczba 666 związana jest z okresem sześciu tysięcy lat trwania wszechświata, reprezentując wszystkie powszechne apostazje ${ }^{129}$. Według Cezarego z Arles cyfra ta jest symbolem heretyków, a w sensie szerszym - antychrysta ${ }^{130}$. Według Bedy Czcigodnego liczba antychrysta oznacza honori contrarium ${ }^{131}$. Podobną wypowiedź spotykamy u Ambrożego Autpert, gdzie wyrażenie honori contrarius odnosi się do antychrysta ${ }^{132}$. Przedstawiciel średniowiecznego mistycyzmu Joachim z Fiore w Komentarzu do Apokalipsy, napisanym w latach 1188-1192, wymienia również trzy szóstki jako liczbę Bestii ${ }^{133}$, jednocześnie przyjmując koniec stulecia, czyli rok 1200 , za datę przybycia antychrysta ${ }^{134}$, i nazywając Goga ultimus Antichristus ${ }^{135}$. Bonawentura występując przeciwko wieczności świata, apokaliptyczną liczbę 666 określa mianem numerus cyclicus, wiążąc

${ }^{123} \mathrm{Na}$ temat liczby 666 zob. J.M. Chevalier, A Postmodern Revelation: Signs of Astrology and the Apocalypse, Toronto 1997, 132; E.F. Edinger, Archetype of the Apocalypse, s. 112-116.

${ }^{124}$ Por. Tertullianus, De resurrectione carnis 25, 1, ed. J.G.P. Borleffs, CCL 2, Turnhout 1996, 953.

${ }^{125}$ Por. Gregorius Illiberitanus, Tractatus Origenis de libris Sanctarum Scripturarum 18, 15, ed.

V. Bulhart - J. Fraipont, CCL 69, Turnhout 1967, 134; 18, 17, CCL 69, 134.

${ }^{126}$ Por. Primasius, Commentarius in Apocalypsin IV 13, CCL 92, 205.

${ }^{127}$ Por. Ambrosius Autpertus, Expositio in Apocalypsin VI 13, 18, CCCM 27A, 516-517.

${ }^{128}$ Por. Irenaeus Lugdunensis, Adversus haereses V 30, 4, SCh 153, 384.

${ }^{129}$ Por. tamże V 28, 2, SCh 153, 356.

${ }^{130}$ Por. Caesarius Arelatensis, Expositio in Apocalypsim 11, PL 35, 2444.

${ }^{131}$ Beda Venerabilis, Explanatio Apocalypsis II 13, PL 93, 172.

${ }^{132}$ Por. Ambrosius Autpertus, Expositio in Apocalypsin VI 13, 18, CCCM 27A, 518.

${ }^{133}$ Por. Joachim de Flore, Expositio in Apocalypsim 4, ed. Selge, s. 60.

${ }^{134}$ Por. McGinn, The Calabrian Abbot, s. 30.

${ }^{135}$ Por. tamże, s. 111. 
ją z obrotami czasu i ruchem gwiazd niebieskich, w sensie zaś szerszym określa nią bestię z Apokalipsy ${ }^{136}$.

Starożytność chrześcijańska jak i wczesne średniowiecze (Beatus z Liébana) widziało w symbolice antychrysta, przedstawionego jako „bestia o dziesięciu rogach i siedmiu głowach”, cesarzy pogańskiego Rzymu, z którymi wiąże się czas prześladowania Kościoła ${ }^{137}$. Szczególnie bowiem w okresie prześladowań uważano, że antychrystem są kolejni władcy rzymscy, państwo zaś rzymskie utożsamiano z czasem panowania antychrysta.

\section{APOSTAZJA I ANTYCHRYST}

Przed powtórnym przyjściem Chrystusa, Kościół musi przejść przez końcowe doświadczenie nazwane ostatecznym prześladowaniem (novissima persecutio), spowodowane przybyciem antychrysta ${ }^{138}$. Prześladowanie ukaże „tajemnicę niegodziwości" w postaci odstępstwa od religijności i prawdy. Pismo Święte opisując okoliczniości powtórnego przyjścia Chrystusa i znaki charakteryzujace czasy ostateczne wymienia wśród nich „odstępstwo" nazwane „tajemnicą bezbożności" (mysterium iniquitatis, por. 2Tes 2, 7) ${ }^{139}$, oraz pojawienie się „człowieka grzechu”, „syna zatracenia”, „niegodziwca”, „który się sprzeciwia i wynosi ponad wszystko, co nazywa się Bogiem lub tym, co odbiera cześć, tak że zasiądzie w świątyni Boga dowodząc, że sam jest Bogiem” (2Tes 2, 3-4).

„Tajemnica niegodziwości” pozostaje w opozycji do „tajemnicy pobożności" (sacramentum pietatis, por. 1Tm 3, 16), która w teologii biblijnej oznacza Wcielenie Syna Bożego w „ostatnich czasach”, według św. Piotra (1P 1, 20). Analogiczną wypowiedź spotykamy w Liście do Hebrajczyków w którym czytamy: ,raz jeden ukazał się teraz na końcu wieków na zgładzenie grzechów przez ofiarę z samego siebie" (Hbr 9, 26). Dlatego też Teodoret z Cyru w Komentarzu do Izajasza powie, że łaska Wcielenia jest znakiem miłosierdzia i dobroci ${ }^{140}$.

Św. Paweł wymienia również pełną mocy „działalność szatana”, połączoną z „oszustwami” i „fałszywymi cudami”, który zwodzić będzie tych, „którzy nie uwierzyli prawdzie", ku nieprawości (2Tes 2, 9-12). W konsekwencji uwierzą oni kłamstwu. Apostoł Narodów zapowiada przewrotność w ostatnich dniach:

${ }^{136}$ Por. Bonaventura, Collationes de septem donis Spiritus sancti 8, 16, ed. P.P. Collegii AS Bonaventura, w: Doctoris Seraphici S. Bonaventurae Opuscula Varia Theologica, vol. V, Ex Typographia Collegii S. Bonaventurae 1891, 497.

${ }^{137}$ Beatus Liebanensis, Commentarius in Apocalypsin XI, ed. Romero-Pose, II, s. 360.

${ }^{138}$ Augustinus, De civitate Dei XVIII 53, 1, BAug 36, 676-679; XX 8, 3, BAug 37, 226-231; XX 10, BAug 37, 244-249. Por. Ap 20, 7-8. Zob. Bardy, Notes. Gog et Magog, w: BAug 37, 777378); Augustinus, De civitate Dei XXI 26, 4, BAug 37, 498-501.

${ }^{139}$ Augustinus, De civitate Dei XX 18-20, 2, BAug 37, 272-291; tenże, Epistula 199, 3. 10, CSEL 57, 252.

${ }^{140}$ Por. Theodoretus Cyrensis, Interpretatio in Isaiam 63, 7, ed. J.-N. Guinot, SCh 315, Paris 1984, 292. Zob. Augustinus, Enarrationes in PS. 103 (2), 5, CCL 40, 1493-1494. 
„Ty zaś wiedz, że w ostatnie dni nastaną czasy niebezpieczne. Będą ludzie samolubni, chciwi, hardzi, pyszni, bluźniercy, rodzicom nieposłuszni, niewdzięczni, zbrodniczy, bez serca, nieprzejednani, potwarcy, niepowściągliwi, okrutni, nielitościwi, zdrajcy, zuchwalcy, nadęci i miłujący bardziej rozkosze niż Boga" (2Tm 3, 1-5; por. Mk 7, 21-22; Mt 15, 19; Ga 5, 19-23; 1Kor 6, 9-10; $1 \mathrm{Tm}$ 1, 9-10; Oz 4, 2; Am 8, 10).

„Duch zaś jawnie mówi, że w czasach ostatecznych niektórzy odstąpią od wiary, przystaną do duchów uwodzicieli i do nauk czartowskich, w obłudzie mówiących kłamstwo i mających napiętnowane sumienie swoje, zakazujących wstępować w małżeństwo, wstrzymywać się od pokarmów, które Bóg stworzył [...]" (1Tm 4, 1-3).

Św. Piotr zapowiadając powtórne przyjście Chrystusa pisze tak:

„To przede wszystkim wiecie, że przyjdą w ostatnich dniach szydercy pełni szyderstwa, którzy będą postępowali według własnych żądz i będą mówili: Gdzie jest obietnica Jego przyjścia?" (2P 3, 3-4).

Juda powołuje się na te wypowiedzi, pisząc:

„Wy zaś, umiłowani, przypomnijcie sobie te słowa, które były zapowiedziane przez Apostołów [...], gdy mówili do was, że w ostatnich czasach pojawią się szydercy, którzy będą postępowali według własnych pożądliwości” (Jud 17-18).

Jedynie w pismach św. Jana występuje termin antychryst, rozumiany jako „duch fałszu” (1J 4, 6), nieprzyjaciel Ewangelii, przeciwnik Chrystusa, który poprzedzi Jego powtórne przyjście i koniec świata. W podobny sposób wypowiedział się Augustyn: „antichristus, contrarius est Christo"141. Podobnie Beatus z Liébana w Komentarzu do Apokalipsy, powie: „Christus ergo anti, id est contrarius Christo (anti enim contra dicitur)" "142. Według św. Jana, antychryst neguje Wcielenie Syna Bożego oraz boskie pochodzenie Jezusa: „Wielu bowiem pojawiło się na świecie zwodzicieli, którzy nie uznają, że Jezus Chrystus przyszedł w ciele ludzkim. Taki jest zwodzicielem i Antychrystem" (2J 7). „Po tym poznajecie Ducha Bożego: każdy duch, który uznaje, że Jezus Chrystus przyszedł w ciele, jest z Boga. Każdy zaś duch, który nie uznaje Jezusa, nie jest z Boga; i to jest duch Antychrysta, który - jak słyszeliście nadchodzi i już teraz przebywa na świecie" (1J 4, 2-3). Antychryst jest kłamcą i uwodzicielem, ponieważ nie uznaje ani Ojca ani Syna, nie wyznaje że Jezus jest Bogiem, ani że Chrystus przybył w ciele (por. 1J 2, 22) ${ }^{143}$. Św. Piotr poucza chrześcijan: „Taka bowiem jest wola Boża, abyście przez dobre uczynki

${ }^{141}$ Augustinus, In Ioannis epistulam ad Parthos tractatus 3, 4, ed. P. Agaësse, SCh 75, Paris 1994, 190.

${ }^{142}$ Beatus Liebanensis, Commentarius in Apocalypsin VI, ed. Romero-Pose, II, s. 162.

${ }^{143}$ Według Bedy (In Epistola Sancti Johannis Apostoli prima 4, PL 93, 106-107), heretycy zostali utożsamieni z antychrystem. 
zmusili do milczenia niewiedzę ludzi głupich. Jak ludzie wolni postępujcie, nie jak ci, dla których wolność jest usprawiedliwieniem zła, ale jak niewolnicy Boga" (1P 2, 15-16).

Pytania „kto będzie antychrystem?”, lub też „kiedy przybędzie wielki uwodziciel i prześladowca?", stymulowały redakcję 1. Listu św. Jana, znajdu-

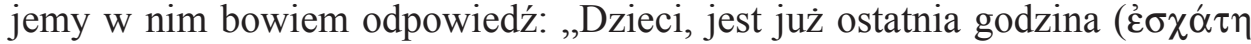

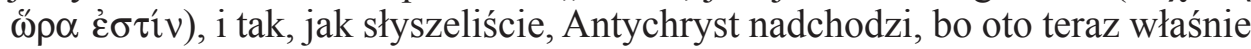
pojawiło się wielu Antychrystów; stąd poznajemy, że już jest ostatnia godzina” (1J 2, 18). Przybycie antychrysta związane jest z „ostatnią godziną”. W literaturze biblijnej czas kresu czasów wiąże się z nadejściem tzw. „fałszywych proroków" (Mt 24, 23-24; Łk 21, 8; Ez 13), głoszących według Jeremiasza „kłamliwe widzenia, zmyślone przepowiednie, urojenia swych serc” (Jr 14, 14). Przestrzega on wysłanników królewskich sąsiednich narodów, przybyłych do Jerozolimy, przed fałszywymi prorokami, którzy prorokując kłamstwo zachęcali do przymierza antybabilońskiego, mówiąc: „Wy natomiast nie słuchajcie waszych proroków, waszych wróżbitów, majacych senne marzenia, waszych przepowiadaczy ze znaków ani waszych czarowników" (Jr 27, 9). Prorok Jeremiasz bowiem w Starym Testamencie dokonał rozróżnienia między prawdziwymi a fałszywymi prorokami (Jr 23, 16-32), przestrzegając naród wybrany przed tymi ostatnimi mówiąc: „Przy końcu dni zrozumiecie to w pełni" (Jr 23, 20). Grzegorz Wielki w jednej ze swych homilii na księgę Ezechiela zwraca uwagę na działalność fałszywych proroków, którzy chcieli przypodobać się swoim słuchaczom i zwieść ich ${ }^{144}$. Sw. Jan naucza:

„Najmilsi, nie każdemu duchowi wierzcie, lecz badajcie duchy, czy są z Boga, gdyż wielu fałszywych proroków wyszło na świat. Po tym poznaje się Ducha Bożego: Każdy Duch, który wyznaje, że Jezus Chrystus przyszedł w ciele, z Boga jest; a każdy duch, który rozrywa Jezusa, nie jest z Boga i ten jest antychryst, o którym słyszeliście, że idzie i teraz już jest na świecie" (1J 4, 1-3).

Alegoryczną interpretację o pochodzeniu antychrysta podaje Beatus z Liébana w Komentarzu do Apokalipsy. Nawiązując do wersetu z Rdz 30, 6 mówiącym o potomstwie Jakuba, któremu niepłodna żona Rachela dała swą niewolnicę Bilhę, z której narodził się Dan, Beatus twierdzi, że z jego pokolenia pochodzi antychryst, bowiem antychryst zrodzony jest $\mathrm{z}$ konkubiny ${ }^{145}$. Beatus jest świadkiem tradycji głoszącej, że antychryst pochodzi z pokolenia Dana.

Zagadnienie dotyczące antychrysta stało się przedmiotem rozpraw teologicznych, za przykład może służyć fragment z Adversus haereses Ireneusza z Lyonu ${ }^{146}$, który wyraźnie mówi o trzech latach i sześciu miesiącach panowa-

\footnotetext{
${ }^{144}$ Gregorius Magnus, Homiliae in Hiezechielem prophetam 10. 14, SCh 327, 396-398.

${ }^{145}$ Por. Beatus Liebanensis, Commentarius in Apocalypsin II Prologus, ed. Romero-Pose, I, s. 183.

${ }^{146}$ Por. Irenaeus Lugdunensis, Adversus haereses V 25-30, SCh 153, 308-386.
} 
nia antychrysta ${ }^{147}$ oraz o czterdziestu dwóch miesiącach panowania Bestii ${ }^{148}$. Hippolit jest autorem traktatu De Antichristo ${ }^{149}$, który wpłynął na eschatologię średniowiecza, czego wyrazem były liczne pisma znane w literaturze średniowiecznej; u Augustyna występują fragmenty mówiące o rozpoznaniu antychrysta ${ }^{150}$; pod koniec VII w. Tajus z Saragossy w piątej księdze Sentencji poświęcił dwa rozdziały tematyce związanej z czasami działalności antychrysta oraz tych, którzy są pod jego panowaniem: De Antichristi temporibus ${ }^{151}$ i De Antichristo vel eius membris ${ }^{152}$. W piątej księdze Sentencji Tajus poświęcił również rozdziały: De Apostatis ${ }^{153}$ oraz De secundo adventu Domini nostri Iesu Christi ${ }^{154}$. Jan z Damaszku († 749) przytacza definicję antychrysta jako adversus Christum ${ }^{155}$, a w 1. poł. IX w. Raban Maur w komentarzu do Drugiego Listu św. Pawła do Tesaloniczan rozdział drugi zatytułował De adventu Antichristi ${ }^{156}$, zaś w X w. Adso z opactwa w Montier-en-Der pozostawił po sobie traktat o antychryście ${ }^{157}$. Z końca XIII w. pochodzi traktat o czasach antychrysta i końcu świata, którego autorem jest świecki teolog hiszpański Arnold $\mathrm{z}$ Villanova ${ }^{158}$. Jego nauka została jednak potępiona przez inkwizycję w czasach Klemensa V. W świetle prorockiego przesłania pojawieniu się antychrysta towarzyszyć będzie objawienie Chrystusa tak, że wyraźnie zostanie rozróżnione regnum Christi od regnum satanae, to ostatnie będzie jednak całkowicie unicestwione ${ }^{159}$.

\section{WYDARZENIA ESCHATOLOGICZNE: KATASTROFY KOSMICZNE}

W okresach przełomowych historii Kościoła, naznaczonych najazdami ludów barbarzyńskich, inwazją islamu, wojnami, prześladowaniami religijnymi, schyłkiem stulecia, pisarze chrześcijańscy widzieli realizację biblijnych

${ }^{147}$ Por. tamże V 25, 4, SCh 153, 322; V 30, 4, SCh 153, 386.

${ }_{148}$ Por. tamże V 28, 2, SCh 153, 352.

${ }^{149}$ Hippolytus, De Christo et Antichristo, PG 10, 725-788; Ippolito, L'Anticristo, a cura di E. Norelli, Firenze 1987; Hippolytus, De Antichristo (Traités d'Hippolyte sur David et Goliath, sur le Cantique des cantiques et sur l'Antéchrist), version géorgienne éditée par G. Garitte, CSCO 263, Leuven 1965, 71-116. Por. Origenes, Conta Celsum VI 45-46, ed. P. Koetschau, GCS 3, Leipzig $1899,115-118$.

${ }^{150}$ Por. Augustinus, In Ioannis epistulam ad Parthos tractatus 3, 4-10, SCh 75, 190-204.

${ }^{151}$ Taio Caesaraugustanus, Sententiarum liber V 26, PL 80, 978-981.

152 Tamże V 27, PL 80, 981-982.

${ }^{153}$ Tamże V 15, PL 80, 971-972.

${ }^{154}$ Tamże V.28, PL 80, 982-983.

${ }_{155}$ Joannes Damascenus, De fide orthodoxa IV 26, PG 94, 1215-1218.

${ }^{156}$ Por. Rabanus Maurus, Expositio in Epistolam II ad Thesalonicenses 2, PL 112, 569-574.

${ }^{157}$ Adso Dervensis, De ortu et tempore Antichristi, necnon et tractatus qui ab eo dependunt, ed.

D. Verhelst, CCCM 45, Turnhout 1976, 20-166.

${ }^{158}$ Por. R. Manselli, Arnoldo de Villanova e i papi del suo tempo, „Studi Romani” 7 (1959) 146-149.

${ }^{159}$ Por. Käsemann, The beginning of Christian Theology, s. 41. 
wizji eschatologicznych. Tak też większość komentarzy do księgi Ezechiela, Daniela i Apokalipsy była wynikiem okoliczności historycznych. Wydarzenia przeszłe aktualizowano w „teraźniejszości”, której nadawano wymiar eschatologiczny. Do tych pisarzy zalicza się Quodvultdeus, biskup Kartaginy, który wygłosił kazanie: De cataclysmo ${ }^{160}$. Przypisywane zaś jemu dzieło De promissionibus et praedictionibus Dei ${ }^{161}$ jest autorstwa raczej Pseudo-Prospera. Każda bowiem przepowiednia prorocka czy wizja eschatologiczna w pewnym sensie realizuje się w kontekście historycznym, niemniej jednak prawdziwa jej interpretacja znajduje się na płaszczyźnie filozoficzno-teologicznej. Tak bowiem jak starożytna literatura chrześcijańska łączyła apokaliptyczne postacie osobowe z władcami Imperium Rzymskiego, tak też średniowiecze, w całkowicie nowej sytuacji politycznej, wyolbrzymiało wizje kataklizmów i katastrof dotyczących ludzkości.

W wypowiedzi proroka Ezechiela: „Koniec, koniec nadchodzi dla czterech krańców ziemi" $(E z 7,1)$ ważny pozostaje przedstawiony tu obraz świata ze swymi czterema punktami kardynalnymi ${ }^{162}$. Przypominamy sobie, że Ewangelia głoszona jest w cztery kierunki świata. Taka była wola wyboru czterech Ewangelistów i dwunastu Apostołów, aby poszli w cztery strony świata, głosząc tajemnicę Trójcy Świętej. Ta liczbowa interpretacja znana była zarówno w literaturze wczesnochrześcijańskich, jak i średniowiecznych pisarzy ${ }^{163}$. W Komentarzu do Daniela Hipolit zwraca uwagę, że czym innym jest całkowite unicestwienie, a czym innym spustoszenie ${ }^{164}$.

W księdze Joela znajduje się opis nastania dnia Pańskiego któremu towarzyszyć będą, charakterystyczne dla apokaliptyki żydowskiej, kataklizmy ziemskie i katastrofy kosmiczne. „I uczynię znaki na niebie i na ziemi; krew i ogień, i słupy dymne. Słońce zamieni się w ciemność, a księżyc w krew, gdy przyjdzie dzień Pański, dzień wielki i straszny" (Jl 3, 3-4). Podobny opis znajduje się w księdze proroka Izajasza: „Księżyc się zarumieni, słońce się zawstydzi, bo zakróluje Pan Zastępów na górze Syjon i w Jeruzalem” (Iz 24,

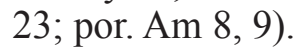

Teologiczna myśl, że Bóg stwórca wszechświata i człowieka ukazał w Jezusie Chrystusie największą miłość do stworzeń, stanowi podstawę eschatologii apokaliptycznej. I kiedy stworzenie odrzuca zamiar Stwórcy, Bóg ukazuje swoją moc w zjawiskach przyrody, co wyraźnie zostało ukazane w scenie ukrzyżowania: „A oto zasłona przybytku rozdarła się na dwoje z góry na dół; ziemia zadrżała i skały zaczęły pękać" (Mt 27, 51). W wersji zaś Łukasza

${ }^{160}$ Por. Quodvultdeus, De cataclysmo (Sermo 7), ed. R. Braun, CCL 60, Turnhout 1976, 409-420.

${ }^{161}$ Por. tenże, De promissionibus et praedictionibus Dei, PL 51, 733-854.

162 Por. Primasius, Commentarius in Apocalypsin V 20, CCL 92, 278.

${ }_{163}$ Por. Augustinus, Sermo 203, 3, 3, PL 38, 1036; tenże, Enarrationes in Ps. 86, 4, CCL 39, 1201; Beatus Liebanensis, Commentarius in Apocalypsin XII, ed. Romero-Pose, II, s. 393.

${ }^{164}$ Por. Hippolytus, Commentarii in Danielem 4, 54, SCh 14, 220. 
i Marka czytamy: „Było już około godziny szóstej i mrok ogarnął całą ziemię aż do godziny dziewiątej. Słońce się zaćmiło i zasłona przybytku rozdarła się przez środek" (Łk 23, 44-45; por. Mk 15, 33. 38). Biblijne wizje katastrof kosmicznych, czyli „znaki na niebie” które towarzyszyć będą objawieniu się w chwale Syna Człowieczego, spełniają rolę ostrzeżenia człowieka, wzywając go do całkowitego nawrócenia. Znane w Starym Testamencie kataklizmy i katastrofy kosmiczne zachowują również w Nowym Testamencie wymiar ostatecznej kary Bożej. Kiedy katastrofy kosmiczne dotyczą całej ziemi, to kataklizmy, takie jak cyklony, powodzie, susza, trzęsienia ziemi, choroby i epidemie, dotykają tylko poszczególnych obszarów zamieszkanej ziemi, grup ludzi, narodów. W Starym Testamencie wielokrotnie wymieniane są równocześnie trzy lub cztery tradycyjne klęski spowodowane przez cztery elementy świata, do których zaliczają się ziemia, powietrze, woda i ogień, a mianowicie: „ogień, grad, głód, śmierć” (Syr 39, 29; 40, 9), „spustoszenie i zagłada, głód i miecz” (Iz 51, 19), „miecz, głód, zaraza” (2Krn 20, 9; Jr 14, 12) „nędza, głód, miecz i zaraza” (Ba 2, 25), „miecz, głód, dzikie zwierzęta i zaraza” (Ez 14, 21). Kataklizmy ziemskie występują też jako towarzyszące opisom wydarzeń biblijnych, na przykład potop (Rdz 6, 17; 7, 1 - 8, 18; 9, 11. 15; Ps 29[28], 10; $\mathrm{Na}$ 1, 8; Mt 24, 38-39; Łk 17, 26-27), trzęsienia ziemi (Iz 24, 19-20; 29, 6; Am 1, 1; Ha 3, 6; Za 14, 5; Mt 24, 7; 28, 2; Mk 13, 8; Łk 21, 11; Ap 6, 12; 11, 13. $19 ; 16,18)$, susza (Kpł 26, 18-20; Jr 14, 1-10), klęski głodu (Rdz 41, 27; Lb 21,$5 ; 1 \operatorname{Krl} 8,37=2 \operatorname{Krn} 6,28 ; 2 \operatorname{Krl} 8,1$; Syr 40, 9; Mt 24, 7; Mk 13, 8), zaraza (2Sm 24, 15). Ewangelie Mateusza i Marka zapowiadają, że czas trwania tych kataklizmów będzie skończony, gdyż Bóg nie chce unicestwić swego stworzenia (Mt 24, 22; Mk 13, 20): „I gdyby Pan nie skrócił owych dni, nikt by nie ocalał. Ale skrócił te dni z powodu wybranych, których sobie obrał". W biblijnej literaturze apokaliptycznej okres eschatologicznego pokoju i szczęścia jest poprzedzony czasem nieszczęść.

W mowie eschatologicznej Chrystus zapowiedział zburzenie miasta świętego Jerozolimy i swoje powtórne przyjście poprzedzające koniec świata:

„Zaraz też po ucisku owych dni słońce się zaćmi i księżyc nie da swego blasku; gwiazdy zaczną padać z nieba i moce niebios zostaną wstrząśnięte. Wówczas ukaże się na niebie znak Syna Człowieczego, i wtedy będą narzekać wszystkie narody ziemi; i ujrzą Syna Człowieczego, przychodzącego na obłokach niebieskich z wielką mocą i chwałą" (Mt 24, 29-30; por. Mk 13, 26; Łk 21, 27).

Formuły ewangeliczne oznaczające dni ostateczne, czyli koniec czasów, ogłaszają interwencję Boga i Jego zwycięstwo nad siłami zła. Nie należy zapominać, że u starożytnych ludów wschodnich gwiazdy były to boskie oblubienice wszechświata. Gdy jest więc mowa o zaćmieniu słońca, o gwiazdach spadających, oznacza to zwycięstwo Jedynego Boga nad idolatrią pogańską. Dla biblijnego autora zaburzenia kosmiczne były sposobem wyrażenia zwy- 
cięstwa Boga nad nieprzyjacielami Izraela. Wizja nadchodzącego Syna Człowieczego jest biblijnym odpowiednikiem wizji wniebowstapienia, w Dziejach Apostolskich czytamy: „Ten Jezus, wzięty od was do nieba, przyjdzie tak samo, jak widzieliście Go wstępującego do nieba" (Dz 1, 11). Ewangelie Mateusza i Marka opisują nadzwyczajne wydarzenia kosmiczne, spowodowane zachwianiem się ruchu planet na orbitach: „zaćmienie słońca”, „księżyc pozbawiony blasku”, „gwiazdy spadające z nieba" rozumiane jako komety i asteroidy (por. Jl 2, 10; Mt 24, 29; Mk 13, 24-25; Łk 21, 25-26). Czyż w tych wypowiedziach nie odnajdujemy reminiscencji starotestamentalnych z wizji proroka Izajasza, który w proroczej groźbie ogłasza wyrok i przepowiada karę dla Babilonu?: „Bo gwiazdy niebieskie i Orion nie będą jaśniały swym światłem, słońce sie zaćmi od samego wschodu, i swoim blaskiem księżyc nie zaświeci” (Iz 13, 10). Kara jaka spotka Babilon przyrównana może być do kary jaka spadła na Sodomę i Gomorę (por. Iz 13, 19). W Ewangelii Łukasza natomiast czytamy o „znakach na ziemi”: „Powstanie naród przeciw narodowi i królestwo przeciw królestwu. Będą silne trzęsienia ziemi, a miejscami głód i zaraza; ukażą się straszne zjawiska i wielkie znaki na niebie" (Łk 21, 10-11; Mt 24, 7; Mk 13, 8a). W interpretacji tej wypowiedzi Augustyn posługuje się koncepcją „dwóch państw”. Ileż to wojen było na ziemi, w różnych epokach i różnych miejscach wzbudzających wstręt i odrazę. Augustyn odwołuje się do najazdów barbarzyńców w czasach cesarza Galiena na wszystkie prowincje rzymskie, kiedy uwierzono, że zbliża się koniec świata. Jakie więc będą wojny, które poprzedzą koniec świata? Te zaś przepowiedziane wojny nie powinny być zrozumiane inaczej jak tylko jako te, które wybuchną przeciwko Kościołowi, ponieważ są tylko dwa narody i dwa królestwa: jeden należący do Chrystusa, drugi do szatana. To w tym sensie Chrystus powiedział: „Powstanie naród przeciw narodowi i królestwo przeciw królestwu"165.

Apokaliptyczny język Pisma Świętego w sposób alegoryczny i metaforyczny bardzo dobitnie ukazuje nadzwyczajne wydarzenia, kataklizmy i klęski żywiołowe, które poprzedzą owe wielkie zamieszanie we wszechświecie dotyczące czasów ostatecznych (por. Mt 24, 26-28; Mk 13, 24-27; Łk 21, 25 28). Jeśli o „znakach na ziemi” możemy stanowczo twierdzić, że pojawiają się one w sposób cykliczny, to na temat „znaków na niebie” nie możemy wyjść poza teren hipotez, bardziej lub mniej uzasadnionych. „A tego dnia, którego Lot wyszedł z Sodomy, spadł deszcz ognisty i siarczysty z nieba, i wszystkich wytracił. Podobnie stanie się w dzień, w którym Syn Człowieczy się objawi” (Łk 17, 29-30; 2P 2, 6-10). Posługując się obrazem kary jaka dotknęła mieszkańców Sodomy, Hipolit ukazuje, jak będzie wyglądał koniec świata ${ }^{166}$. Powrót Syna Człowieczego będzie również powrotem człowieka do Chrystusa. Zapowiedzi eschatologiczne zbliżającego się kresu czasów łączą się z tzw. „odsłonięciem się nieba”, co w sensie literalnym oznacza apokalipsę, ukaza-

${ }^{165}$ Augustinus, Epistula 199, 10. 35, CSEL 57, 274; por. Mt 3, 2; 1Tes 5, 1-11.

${ }^{166}$ Por. Hippolytus, Commentarii in Danielem 4, 6, SCh 14, 272. 
nie „mieszkań w domu Ojca” oraz miejsca kar wiecznych. Św. Piotr opisuje wydarzenia eschatologiczne w następujący sposób: „Jak złodziej zaś przyjdzie dzień Pański, w którym niebo ze świstem przeminie, gwiazdy się w ogniu rozsypią, a ziemia i dzieła na niej zostaną zniszczone" $(2 \mathrm{P} 3,10.12)$. Jan również opisuje wizję Chrystusa otwierającego szóstą pieczęć księgi zapieczętowanej: „a oto powstało wielkie trzęsienie ziemi i słońce stało się czarne jak wór włosienny i cały księżyc stał się jak krew i gwiazdy z nieba spadały" (Ap 6, 12-13). Według Wiktoryna z Petawium ta wizja dotyczy ostatniego prześladowania, wskutek którego ludzie opuszczą Kościół ${ }^{167}$. Apokalipsa zawiera opisy eschatologicznych wizji: „I zatrąbił anioł czwarty i porażona została trzecia część słońca i trzecia część księżyca i trzecia część gwiazd, tak że ich trzecia część się zaćmiła i przez trzecią część dnia nie było światła i podobnie w nocy" (Ap 8,12). Przestrogi apokaliptycznej wizji są analogiczne do tych, które Jeremiasz skierował do ludów, aby im oznajmić ogrom gniewu Bożego (por. Jr 25, 15-38), a także do przepowiedni Ezechiela: „Jedna trzecia twoja pomrze od zarazy i zginie pośrodku ciebie od głodu; jedna trzecia padnie wokół ciebie od miecza, a jedną trzecią rozpędzę na wszystkie wiatry, nadto miecza nad nimi dobędę" (Ez 5, 12). Apokalipsa opisuje, że kataklizmy, które dotkną ziemię, zostaną spowodowane przez cztery istoty niszczycielskie: „I rozwiązani zostali czterej aniołowie, którzy byli gotowi na godzinę i dzień, i miesiąc, i rok, aby zabić trzecią część ludzi” (Ap 9, 15). Hipolit widział w „,czterech aniołach siedzących nad wielką rzeką Eufrat” Persów, Medów, Asyryjczyków i Babilończyków ${ }^{168}$. Beatus z Liébana zaś uważał, że okres ten, zwany „czasem antychrysta”, trwać będzie trzy lata i sześć miesięcy ${ }^{169}$. Autor Apokalipsy ujrzał w widzeniu konie, z których pysków wychodziły: „ogień, dym i siarka", oznaczające karę Bożą, podobną do tej, która dotknęła Sodomę i Gomorę według Rdz 19, 24. 28, wskutek której została zabita „trzecia część ludzi” (Ap 9, 18). W Księdze Ezechiela Bóg zapowiada zemstę przeciwko Gogowi: „I wymierzę mu karę przez zarazę i krew, i ulewę, i grad jakby kamieni. Ogień i siarkę ześlę jak deszcz na niego i na jego wojsko, i na rozliczne ludy, które są z nim" (Ez 38, 22). Przepowiednia Ezechiela ukazana została w apokaliptycznej wizji: „I zstąpił ogień z nieba od Boga i pożarł ich, a diabeł, który ich zwodził, wrzucony został w jezioro ognia i siarki, gdzie i bestia i fałszywy prorok będą męczeni we dnie i w nocy na wieki wieków" (Ap 20, 9-10). Na podstawie tych tekstów możemy stwierdzić, że terminologia prorockich przepowiedni i opisów apokaliptycznych wizji, a nawet teofanii, jest bardzo do siebie podobna: ,[...] nastąpiły błyskawice, głosy, gromy, trzęsienie ziemi i wielki grad" (Ap 11, 19). Teofanii na Bożej górze Horeb, jaką miał Eliasz towarzyszyły podobne zjawiska: „Gwałtowna wichura rozwalająca góry i dru-

${ }^{167}$ Por. Victorinus Poetovionensis, Commentarii in Apocalypsim Ioannis 6, 5, ed. M. Dulaey, SCh 423, 82.

${ }^{168}$ Por. Hippolytus, Commentarii in Danielem 3, 9, SCh 14, 216.

${ }^{169}$ Por. Beatus Liebanensis, Commentarius in Apocalypsin V, ed. Romero-Pose, II, s. 43. 
zgocąca skały szła przed Panem; ale Pan nie był w wichurze. A po wichurze - trzęsienie ziemi: Pan nie był w trzęsieniu ziemi. Po trzęsieniu ziemi powstał ogień: Pan nie był w ogniu. A po tym ogniu szmer łagodnego powiewu" (1Krl 19, 11-12). Zawarty w języku apokaliptycznym element zwany „misterium” oraz brak precyzji w określeniach czasu stanowią tzw. ,atmosferę” literatury apokaliptycznej ${ }^{170}$.

W księdze Apokalipsy czytamy o „trzech duchach nieczystych”, czyli demonach, które zgromadzą wszystkich królów ziemi na wojnę w „dniu wszechmogącego Boga" w miejscu zwanym po hebrajsku Har-Magedon (Ap 16, 1314. 16) ${ }^{171}$. Według Cezarego z Arles zgromadzeni tam reprezentują trzy grupy ludzi: pogan, heretyków i ,fałszywych chrześcijan"172. Beatus z Liébana odnosi to zgromadzenie ,na wojnę" (Armageton) do czasów antychrysta, rozumianych jako ostateczne prześladowanie (novissima persecutio) ${ }^{173}$.

Zagłady opisane w Apokalipsie jako „kataklizmy ziemskie” spowodują upadek „Wielkiego Babilonu” (Ap 17, 5), symbolu pogaństwa i idolatrii, którego nazwa nie oznacza nic innego jak ,wielkie zamieszanie”, dotyczące również życia Kościoła ${ }^{174}$ : „Dlatego w jednym dniu przyjdą jej plagi: śmierć i smutek, i głód; i będzie ogniem spalona, bo mocny jest Pan Bóg, który ją osądził” (Ap 18, 8). Św. Paweł podaje dualistyczną definicję smutku: ,smutek, który jest z Boga, dokonuje nawrócenia ku zbawieniu, którego się potem nie żałuje, smutek zaś tego świata sprawia śmierć" (2Kor 7, 10). Chrystus, Stwórca wszechrzeczy, określany jest metaforycznym zwrotem jako „Pan nieba i ziemi" (Mt 11, 25; Łk 10, 21). Wydarzenia eschatologiczne opisane w literaturze biblijnej, związane z dualistyczną koncepcją świata, ukazują w konsekwencji ostatczne zwycięstwo dobra nad złem, identyfikowanym w apokaliptycznych wizjach Pisma Świętego ze wszelkimi przejawami pogaństwa. W rozprawach zaś filozoficzno-teologicznych średniowiecza powrócą rozważania de aeternitate mundi, kwestionujące wieczność materialnego świata. Teologowie argumentując nie tylko za tym, że świat ma początek, ale również za jego kresem, przedstawiali całkowitą i stałą zależność świata w jego relacji do Boga.

\section{MILLENARYZM WEDŁUG APOKAKLIPSY (AP 20, 2-7)}

Stosownie do mentalności starożytnego Wschodu przy pomocy apokaliptycznych symboli liczbowych starano się wyjaśnić prawdy teologiczne. Schematyzacja czasu ograniczonego do siedmiu dni, siedmiu tygodni, prowadziła również do periodyzacji historii wyznaczonej przez siedem okresów. Traktowanie historii przez apokalipsę nie ograniczało się tylko do jej podziału na

\footnotetext{
${ }^{170}$ Por. Collins, The Apocalyptic imagination, s. 13.

${ }^{171}$ Por. Chevalier, A Postmodern Revelation, s. 159.

${ }^{172}$ Caesarius Arelatensis, Expositio in Apocalypsim 13, PL 35, 2448; 18, PL 35, 2456.

${ }^{173}$ Beatus Liebanensis, Commentarius in Apocalypsin VIII, ed. Romero-Pose, II, s. 255-256.

${ }^{174}$ Por. tamże, ed. Romero-Pose, II, s. 271.
} 
okresy, lecz także odznaczało się ukazaniem grzechu i zbawienia w konkretnych sytuacjach. U Izraelitów istniało wierzenie we władzę ziemską Mesjasza, którego przybycie miało zapoczątkować erę obfitości i szczęścia w Izraelu ${ }^{175}$. Pojawiła się bowiem teoria o szczęściu mesjańskim i w tej perspektywie zaczęto rozróżniać między odwiecznym królowaniem Boga a królowaniem pośrednim o trwaniu ograniczonym, które powinno być zlokalizowane w raju ziemskim lub w Niebieskim Jerusalem, które zstąpiło na ziemię, aby przyjąć sprawiedliwych z Izraela. Ta teoria znajduje się w Księdze Jubileuszy (22, 27), gdzie zapowiedziano, że ludzie żyć będą dłużej, nie będzie starców, a będą tylko dzieci i ludzie młodzi. Trwanie zaś tych czasów mesjańskich nie zostało określone. Wielu uważało że trwać one będą tysiąc lat, co odpowiada sześciu tysiącom lat trwania obecnego świata, bowiem jeden dzień w oczach Bożych jest jak tysiąc lat (por. Ps 89, 4; zob. Ps 84[83], 11; 2P 3, 8: ,jeden dzień u Pana jest jak tysiąc lat, a tysiąc lat jak jeden dzień”). Millenaryzm (od łac. mille) lub chiliazm (od grec. $\chi$ í $\lambda$ เoı) bazując na literalnej interpretacji Apokalipsy (Ap 20, 2-7) naucza, że widzialne zasady Chrystusa na ziemi trwać będą tysiąc lat, a po nich nastąpi koniec świata, ,gdy przekaże królowanie Bogu i Ojcu i gdy pokona wszelką Zwierzchność, Władzę i Moc" (1Kor 15, 24). W starożytnym Kościele wierzono, że koniec świata nastąpi tysiąc lat po Chrystusie ${ }^{176}$. Kapłaństwo Chrystusa w królestwie mesjańskim trwać będzie tysiąc lat po „pierwszym zmartwychwstaniu”. Tysiąc lat z Apokalipsy należy rozumieć nie w sensie dosłownym lecz symbolicznym, tak jak ,pierwsze zmartwychwstanie” symbolizuje chrzest święty. Ta „religia apokaliptyczna”, zwana millenaryzmem, jest syntezą doktryny magów chaldejskich o siedmiu tysiącleciach świata i refleksji żydowskiej na temat symboliki siedmiu dni tygodnia ${ }^{177}$. W kręgach żydowskich bowiem nie rozróżniano między królestwem mesjańskim a czasem eschatologicznym. Teoria ta przejęta została przez niektórych heretyków jak Cerynt ${ }^{178}$ oraz ebionitów, a także przez pisarzy wczesnochrześcijańskich np. Papiasza z Hierapolis i Justyna Męczennika, którzy jednak, nie wyolbrzymiając ziemskiego elementu millenaryzmu, widzieli w symbolu ,nowej Jerozolimy" duchową i wieczną rzeczywistość ${ }^{179}$. Według Euzebiusza, Papiasz przekazał heretycką doktrynę chiliazmu Ireneuszowi z Lyonu ${ }^{180}$. Te dni

${ }^{175}$ Por. Iz 54 „wizja Nowej Jerozolimy”; Iz 60 „wizja chwały Jerozolimy”; Ez 40-47 „wizja nowego królestwa Bożego").

${ }^{176}$ Por. E. Weber, Apocalypses. Prophecies, Cults and Millennial Beliefs Throughout the Ages, London 1999. Zob. Augustinus, Epistula 199, 6. 17, CSEL 57, 257.

${ }_{177}$ Por. M. Dulaey, Introduction, w: SCh 423, 39.

${ }^{178}$ Por. Eusebius Caesariensis, HE III 28, 2, ed. G. Bardy, SCh 31, Paris 1952, 137-138; tamże VII 25, 2, SCh 41, Paris 1955, 204-205; Irenaeus Lugdunensis, Adversus haereses I 26, 1, SCh 264, Paris 1979, 344.

${ }^{179}$ Por. komentarze L.W. Barnarda zawarte w przypisach, w: St. Justin Martyr, The First and Second Apologies, Ancient Christian Writers 56, transl. with introduction and notes by L.W. Barnard, Mahwah 1997, 208-211.

${ }^{180}$ Por. Eusebius Caesariensis, HE III 39, 12-13, SCh 31, 156. 
wieczności, ponieważ czas przestanie istnieć, tworzyć będą jeden tylko dzień, bez początku i bez końca, nie będzie on poprzedzany dniem wczorajszym, ani nie nastąpi po nim dzień jutrzejszy ${ }^{181}$. Na początku II w. autor Listu Barnaby ${ }^{182}$ ogłsza, że świat trwać będzie sześć tysięcy lat (por. Hipolit ${ }^{183}$, Beatus z Liéba$n^{184}$, Ambrosius Autpert ${ }^{185}$ ), na początku zaś siódmego tysiąclecia ukaże się Syn Boży, który zniszczy czas niegodziwości i osądzi złych; odnowi słońce, księżyc i gwiazdy i rządzić będzie ze sprawiedliwymi przez tysiąc lat. W tym zakończonym okresie nastąpi przemiana wszystkiego, ósmy dzień oznaczać będzie nastanie nowego i definitywnego świata. Hipolit uważa, że skoro Bóg stworzył świat w ciągu sześciu dni, a jeden dzień dla Boga jest jak tysiąc lat, to świat ten trwać będzie sześć tysięcy lat ${ }^{186}$. Podobną wypowiedź spotykamy u Augustyna, który rozumuje w następujący sposób: skoro Bóg stworzył świat w ciągu sześciu dni, jest więc logiczne, że świat trwa sześć tysięcy lat, po którym nastanie tysiąc lat szczęścia mesjańskiego, co odpowiada dniowi Bożego odpoczynku, wspomnianemu w Księdze Rodzaju (2, 2-3) ${ }^{187}$. Dobrze była znana w tradycji patrystycznej teza głosząca, że Chrystus narodził się pięć tysięcy pięćset lat po Adamie ${ }^{188}$. W tym miejscu należy przypomnieć o liczbowym znaczeniu pełnych symboliki liter abecadłowych u Żydów. $Z$ tych środowisk żydowskich wiara $\mathrm{w}$ rządy mesjańskie została przekazana chrześcijanom za pośrednictwem Apokalipsy.

W przytoczonych opisach zdecydowanie przoduje materialne przedstawienie millenaryzmu, ograniczające się do doczesnego panowania Chrystusa nad sprawiedliwymi pomiędzy paruzją a sądem związanym ze stanem wieczności. W poł. II w. millenaryzm stał się jednym z elementów fundamentalnych chrześcijańskiej wiary (np. Justyn ${ }^{189}$, Papiasz ${ }^{190}$, Ireneusz z Lyonu ${ }^{191}$ ), w kolejnych wiekach ślady millenaryzmu w eschatologii spotykamy u Tertulliana $^{192}$ i Laktancjusza ${ }^{193}$. W II w. millenaryzm osiągnął swe apogeum, natomiast w III w., głównie na skutek krytyki materialistycznego pojmowania obietnic

\footnotetext{
${ }^{181}$ Por. Augustinus, Sermo 86, 9, 10, PL 38, 528; Mt 25, 34. 46.

${ }^{182}$ Por. Epistula Barnabae 15, 4-9, ed. R.A. Kraft - P. Prigent, SCh 172, Paris 1971, 184-188.

${ }^{183}$ Por. Hippolytus, Commentarii in Danielem 4, 23-24, SCh 14, 306-310.

${ }^{184}$ Por. Beatus Liebanensis, Commentarius in Apocalypsin XII, ed. Romero-Pose, II, s. 386.

${ }^{185}$ Por. Ambrosius Autpertus, Expositio in Apocalypsin VI 13, 18, CCCM 27A, 520.

${ }^{186}$ Por. Hippolytus, Commentarii in Danielem 4, 23-24, SCh 14, 306-310.

${ }^{187}$ Por. Augustinus, Sermo 93, 7, 8, PL 38, 576; tenże, Epistula 199, 6. 18, CSEL 57, 258; Hesychius Hierosolymitanus, In Christi natalem, PG 92, 1057-1058; PG 93, 1449-1450; por. A. de Halleux, La chronique melkite abrégée du Ms. Sinaï syr. 10, „Le Muséon” 91 (1978) 17 (nr 3)

${ }^{188}$ Por. O. Mazal, Manuel d'Etudes Byzantines, trad. de l'allemand par C. Detienne, Graz 1995, 245.

${ }^{189}$ Por. Iustinus Martyr, Dialogus cum Tryphone Iudaeo 80, PG 6, 663-668.

${ }^{190}$ Por. Irenaeus Lugdunensis, Adversus haereses V 33, 3, SCh 153, 414-416.

${ }^{191}$ Por. tamże V 28, 3, SCh 153, 358; V 29, 2, SCh 153, 370.

${ }_{192}$ Por. Tertullianus, Adversus Marcionem III 24, 3, ed. A. Kroymann, CCL 1, 542; III 24, 6,

${ }^{193}$ Por. Lactantius, Divinae institutiones VII 24, CSEL 19, 658-659.
} CCL 1, 542. 
eschatologicznych, dokonanej przez wybitnego myśliciela chrześcijańskiego z Aleksandrii - Orygenesa ${ }^{194}$, chylił się ku upadkowi. Nawet kapłan rzymski imieniem Kajusz neguje autentyczność nie tylko Apokalipsy, ale i Czwartej Ewangeli, na co reaguje Hipolit, pisząc apologię Capita contra Gaium ${ }^{195}$.

Św. Jan w Apokalipsie $(20,1)$ opisuje postać anioła zstępującego z nieba, trzymającego w swych dłoniach klucz do przepaści i wielki łańcuch. Ten Anioł panuje nad szatanem, wrzuca go do przepaści i wyprowadza, aby mógł atakować ludzi. Uwięzienie szatana wydłuża się na okres tysiąca lat, a pod koniec tego okresu zostaje uwolniony na krótki czas (por. Ap 20, 2) ${ }^{196}$. Według Augustyna symboliczne „tysiąc lat” oznacza okres czasu od wcielenia Syna Bożego aż do końca świata. Wyjaśnienie to zostało powszechnie potwierdzone. Jednak według Beatusa z Liébana, okres czasu od męki Chrystusa do Jego powtórnego przyjścia obejmować będzie symboliczny czas „tysiąca lat”"197.

Apostoł Jan dodaje, że uwięzienie szatana trwać będzie tysiąc lat (por. Ap 20, 2-3. 7). Bez wątpienia liczba tysiąc jest symboliczna ${ }^{198}$. W rzeczywistości, jeśli szatan został uwięziony w momencie, w którym rozpoczęło się głoszenie królestwa Bożego, pozostanie on uwięziony do chwili bardzo krótkiej, ostatniej walki. Czy można uznać, że ta chwila trwać będzie trzy i pół roku, co również jest liczbą symboliczną, oznaczającą krótkotrwałość ostatniego ataku szatana w przeciwstawieniu się do długiego trwania tysiąca lat? Jeśli zauważymy, że trzy i pół roku jest to czas, który odpowiada publicznej działalności Jezusa Chrystusa, według Ewangelii św. Jana, i wynosi 42 miesiące, a ta liczba z kolei określa trzy serie czternastu pokoleń, o czym mówi genealogia według Mateusza, jak również jest liczbą trzech serii ofiar złożonych dla Jahwe przez Balaka i Balaama, zaś potrojenie czternastu oznacza Dawida, który był figurą par excellence Mesjasza i jednocześnie jego przodkiem, możemy wyciągnąć konkluzję, że okres tysiąca lat, w trakcie którego głoszono Chrystusa, prawdopodobnie jest zbieżny z czasem trzech i pół roku działalności szatana. Sens „trzech i pół roku” należy rozumieć również w odniesieniu do symbolicznego okresu siedmiu lat (rok szabatowy por. Pwt 15, 1-18), którego stanowią połowę. Czy w tej symbolicznej liczbie nie należałoby dostrzec czasu obejmującego okres dwóch Testamentów: Prawa i Ewangelii?

$\mathrm{Z}$ jednej strony, szatan jest uwięziony, lecz jego niewola nie polega na utracie mocy szkodzenia człowiekowi. Alegoryczna interpretacja uwięzienia szatana, pozwoliła Beatusowi z Liébana dostrzec go uwięzionego w złych ludziach, którzy jednak nie mogą szkodzić Kościołowi jako królestwu Bo-

${ }^{194}$ Por. Origenes, De principiis II 11, 2, SCh 252, 396-398.

${ }^{195}$ Por. Hippolytus, Capita contra Gaium, ed. G.N. Bonwetsch - H. Achelis, GCS 1, Leipzig 1897, 241-247; Dionysius Bar Salibi, In Apocalypsim, Actus et Epistulas Catholicas, ed. J. Sedlacek, CSCO 53, Leuven 1909, 3-28.

${ }^{196}$ Por. Victorinus Poetovionensis, Commentarii in Apocalypsim Ioannis 20, 1, SCh 423, 114.

${ }^{197}$ Por. Beatus Liebanensis, Commentarius in Apocalypsin XI, ed. Romero-Pose, II, s. 352.

${ }^{198}$ Por. Hieronymus, In Hiezechielem XI 38, CCL 75, 525. 
żemu ${ }^{199}$. Jeśli zaś on nie może oddziaływać skutecznie na tych którzy naznaczeni zostali znamieniem, ,pieczęcią Jezusa Chrystusa” (Ef 4, 30, 2Kor 1, 21-22; por. Ap 7, 3), czyli namaszczeni (por. 1J 2, 20), okazuje swoją moc nad tymi, którzy nie posiadają tej pomocy i którzy z różnych przyczyn nie chcieli jej przyjąć. $Z$ drugiej zaś strony, dysproporcja, istniejąca między symbolami liczbowymi „tysiąc” a „trzy i pół” na oznaczenie jednego i tego samego okresu współrozciągłego, powoduje na pierwszy rzut oka wielkie zdziwienie. Lecz tutaj, jak i w innych miejscach, należy uświadomić sobie fakt, że często w Apokalipsie Jan nie zwracał uwagi na arytmetyczną relację zachodzącą między cyframi, szukał raczej ich znaczenia moralnego, co może wytworzyć zbieżność sensu cyfr bardzo różnych np. trzy i pół oraz 42 oznaczają jeden aspekt, a 1000 inny aspekt tego samego okresu. W ten też sposób możemy lepiej zrozumieć charakter rządów w symbolicznym czasie tysiąca lat. Według Augustyna te tysiąc lat oznacza więc całą historię świata od nauczania Jezusa Chrystusa, lub jeszcze lepiej od jego śmierci, zmartwychwstania, wniebowstąpienia i założenia Kościoła, aż do powtórnego przyjścia w chwale ${ }^{200}$. Ci wszyscy, którzy po Jezusie Chrystusie zostali wezwani aby sądzić świat i zasiedli na dwunastu tronach, aby sprawować sąd są to święci, męczennicy i wierni, którzy wytrwali w wierze i nie adorowali bestii, ci którzy zresztą zostali ukazani w liczbie 144.000 wybranych ze wszystkich pokoleń Izraela (por. Ap 14, 1. 3). Ta liczba, stanowiąca potęgę biblijnej liczby 12, oznacza mnóstwo lub pełnię. Symboliczna interpretacja tej liczby wyraża, według Beatusa z Liébana, pełnię liczby 12 odnoszącej się do Kościoła ${ }^{201}$. Według zaś Wiktoryna z Petawium ta liczba oznacza ludzi, którzy w czasach ostatecznych (novissimis temporibus) uwierzą, skoro powtórnie przybędzie Eliasz ${ }^{202}$.

Ewangelia mówi o zgromadzeniu wybranych ,z czterech stron świata” (Mt 24, 31; por. Mk 13, 27) ${ }^{203}$. Wszyscy sędziowie stanowią tych, którzy zmartwychwstali, co najmniej jeśli chodzi o pierwsze zmartwychwstanie, które nie jest zmartwychwstaniem ciał, lecz które jest tylko zmartwychwstaniem duchowym (por. Ap 20, 5). Ponieważ zostali oni ochrzczeni, śmierć nie ma już więcej władzy nad nimi; rozumiemy, że chodzi tutaj o śmierć ducha, śmierć duszy, jedyną, która prawdziwie coś znaczy. Sąd ostateczny nastąpi bezpośrednio po zmartwychwstaniu ciał. Według Ojców Kościoła tysiącletnie królowanie Boga nie dotyczy całej ludzkości. Realizuje się tylko dla zbawionych, dla tych którzy duchowo zmartwychwstali, którzy są chrześcijanami i żyją w stanie łaski Bożej. Szatan zaś pomimo, że znajduje się w sytuacji, w której (teoretycznie) nie może szkodzić, zachowuje swoją władzę nad Gogiem i Ma-

${ }^{199}$ Por. Beatus Liebanensis, Commentarius in Apocalypsin IV, ed. Romero-Pose, I, s. 600-601.

${ }^{200}$ Augustinus, De civitate Dei XX 7-20, BAug 37, 210-295.

${ }^{201}$ Por. Beatus Liebanensis, Commentarius in Apocalypsin IV, ed. Romero-Pose, I, s. 603.

${ }^{202}$ Por. Victorinus Poetovionensis, Commentarii in Apocalypsim Ioannis 12, 4, SCh 423, 102.

${ }^{203}$ Por. Origenes, Commentarii in Matthaeum (Mt 24, 31) 51, GCS 38, 115; tamże (Mt 24, 31) 52, GCS 38, 116-117. 
gogiem, ponieważ wielka liczba ludzi nigdy nie była poddana szczerze i całkowicie Chrystusowi. Imperium szatana istnieje nawet w niewoli, gdzie może on sprawować swoją władzę, według słów Piotra: „Przeciwnik wasz, diabeł, jak lew ryczący krąży szukając kogo pożreć” (1P 5, 8).

Dochodzimy więc do konkluzji, że tysiąclecie nie reprezentuje okresu czasu wyróżniającego się w historii, lecz czas uwolnienia bestii. Panowanie szatana jest $\mathrm{z}$ góry skazane na klęskę, a jego zwycięstwa, nawet te najbardziej widoczne, trwać będą tylko krótki okres czasu w porównaniu z wiecznością, podczas gdy rządy Kościoła powinny trwać bez końca, ponieważ jego przeznaczeniem jest nieomylność w sensie dążenia do zwycięstwa. Ta ostateczna walka z szatanem dla Kościoła będzie czasem chwały i nastanie wówczas „nowe niebo i nowa ziemia” (2P 3, 13; Ap 21, 1-2).

Beatus z Liébana w alegorii „drzwi otwartych”, pochodzącej z Apokalipsy (Ap 3, 8), dostrzegł podwójne nauczanie w „dzień” i w „nocy”. W nocy, która jest symbolem ciemności i ignorancji, nauczają hipokryci, heretycy, schizmatycy, pseudo-kapłani, w dzień zaś, który jest symbolem światłości i mądrości, nauczają ,,święci” 204 . Te „drzwi otwarte” to nie tylko symbol możliwości głoszenia Ewangelii przez Apostołów (por. 1Kor 16, 9; 2Kor 2, 12; Kol 4, 3), ale także jest to symbol zupełnego bezpieczeństwa i gościnności, o których mówi prorok Izajasz $(60,11)$. Ponowienie niejako tej wypowiedzi Izajasza spotykamy w Apokalipsie: „I bramy jego [miasto, nowa Jeruzalem] nie będą w dzień zamknięte, albowiem nocy tam nie będzie” $(21,25)$. „Drzwi otwarte” stanowią równocześnie symbol Bożego miłosierdzia (por. J 10, 9): „bramą jest Chrystu-

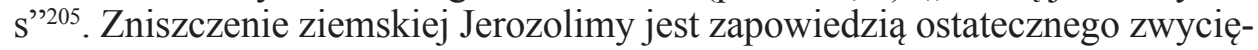
stwa niebiańskiej Jerozolimy, w której panuje miłość, pokój i sprawiedliwość.

$* * *$

Biblijna wizja wydarzeń eschatologicznych ukazuje pozytywnie ostateczne zwycięstwo dobra nad złem, nad szatanem i triumf Kościoła, który jest instytucją Bożą. Posiadający sens mesjański „czas kresu czasów” jest określeniem ukazującym wszechmoc Bożą nad światem, wszechmoc Stwórcy nad stworzeniem. Czas bowiem jest przejawem działalności zbawczej Boga, a także działalności szatana, który pragnie zniszczyć w człowieku Boże wezwanie do zbawienia. A świat który został stworzony z mądrości i miłości Bożej czy mógłby zostać przez swego Stwórcę unicestwiony? To pytanie skierowane jest do każdego. Tak jak czytamy w Księdze Proroka Amosa: „Nie zgładzę jednak zupełnie domu Jakuba - wyrocznia Pana" (Am 9, 8). Prorok Izajasz powie też: „Albowiem z Jeruzalem wyjdzie Reszta i z góry Syjonu garstka ocalałych” (Iz 37, 32). Istnieje bowiem dysproporcja między nieskończoną wielkością Boga a nędzą i ubóstwem człowieka.

${ }^{204}$ Por. Beatus Liebanensis, Commentarius in Apocalypsin XII, ed. Romero-Pose, II, s. 423-424.

${ }^{205}$ Por. tamże, ed. Romero-Pose, II, s. 391. 
Dla Ojców Kościoła stworzenie świata miało ukierunkowanie chrystocentryczne. Nawiązując do wypowiedzi z Ksiegi Mądrości utożsamiali oni Mądrość z Chrystusem: „Z Tobą jest Mądrość, która zna Twe dzieła, i była z Tobą, kiedy świat stwarzałeś [...]" (Mdr 9, 9; por. Prz 8, 30). Stąd też można wnioskować, że w ramach teologii historii kres kresu czasów ma również swoje chrystocentryczne ukierunkowanie i wypełnienie. Na podstawie biblijnej apokaliptyki Ojcowie Kościoła budowali własną interpretację historyczno-teologiczną wydarzeń eschatologicznych. W teologii bowiem czas jest wektorem działalności Boga w ludzkim życiu, jego interwencji szanującej do końca wolność człowieka, a kres czasu jest tym momentem, w którym życie ludzkie jest już tylko całkowicie uzależnione od Boga. Czas bowiem jest zbawczym wydarzeniem w życiu człowieka, kres czasu stanowi zakończenie tej zbawczej interwencji i zbawczej pedagogii Boga względem człowieka.

\section{THE TIME OF THE END OF TIMES \\ IN THE APOCALYPTICAL LITERATURE}

\section{(Summary)}

In this article titled "The Time of the End of Times in the Apocalyptical Literature" the author presents the study about the biblical vision of the final time which concern two domains christological and ecclesiological. This patristic study pertains to several subjects set forth in section and sub-section titles, such as: Christ as the Eternal Day of God, the Parousia as the Second Coming of Christ, the Day of Judgement, the Great Tribulation or Persecution (Mt 24: 21; Mk 13: 19; por. Dan 12: 1), "the great distress" (Rev 7: 14), the time of Pagans persisting for forty two months, the fall of Jerusalem (Mt 24: 1-3; Mk 13: 1-4; Lk 21: 5-7. 20), "abomination of desolation" (Dan 9: 27; 11: 3; 12: 11), Gog and Magog from the vision of Ezekiel (Ezek 38-39) and Apokalypse (Rev 20: 8), a great apostasy will be a prelude to the Second Coming of Christ, "a hundred and forty-four thousand who had his [Lamb's] name and his Father's name written on their foreheads [and] who had been ransomed from the earth" (Rev 14: 1. 3), Antichrist (1Jn 2: 18. 22; 4: 2-3; 2Jn 7) and his time three and a half years (Rev 11: 9. 11) or forty-two months (Rev 11: 2; 13:5). The Antichrist refers to the ruling spirit of error, the enemy of the Gospel, and the opponent of Christ who will precede His Second Coming and the end of the world. He is the incarnation of wickedness, pride, and hostility toward Christ's redemptive work. This section delves into the number $666(\operatorname{Rev} 13: 18 ; 15: 2)$, false prophets (2Pet 2: 1), false teachers (2Pet 2: 1). In the biblical apocalyptic literature we can find a few visions of the cosmic catastrophes and cataclysms such as "earthquakes" (Mt 24: 7; Mk 13: 8), "famines" (Mt 24: 7; Mk 13: 8). In this study, appeared the theory of Millenarianism (from Latin mille) or chiliasm (from Greek $\chi^{i} \lambda \mathrm{tor}$ ) based on a literal interpretation of Apocalypse 
(Rev 20: 2-7) which interpretation teaches that the visible personal rule of Christ on earth will last for a duration of a thousand years before the end of the world.

Two themes are given special study in this article. First is the distinction of the interpretation of time. Second, is the interpretation of the prophetic announcements and eschatological visions from the Bible, and the potential influence of the ancient apocalyptic stories and writings in the redaction of the Bible.

As to the first theme, the application of Greek distinction of concept of time

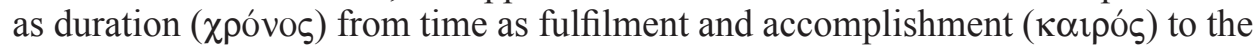
Hebrew conception of time is problematic. Substantial biblical concept of time is an event which pertains to time, otherwise as time having specific event, more then a time extending indefinite time. In the theological perspective, perception of time is therefore an action of God. From the very beginning to the end of Biblical History, time is the means of God's deeds of salvation. Thence for the biblical author, the historic-redemptive (salvation) concept of the world appears before his metaphysical conception. This concept is also readily apparent in the description of the seven days from the ancient Semitic cosmogony well-known from the Book of Genesis.

This topic contains an important christological and messianic aspect. The history of the world become conditioned and dependant, defined and designated by the existence of the Word of God, Creation and Incarnation by the birth of the Son of God, fulfilment of time by the second coming of the Son of Man siting at the right hand of God (Mk 16: 19; Heb 12: 2), the end of time by the judgement of God. One can speak of christological concept of time and also of christological concept of the world.

The discussion of the second theme revolves around the interpretation of the Fathers of the Church on apocalyptic writings. This analysis of the meaning of the apocalyptical symbols is presented according to the interpretation of the Fathers of the Church, starting with all commentary of the Book of Revelation written from the beginning to the $12^{\text {th }}$ Century. Outstanding among Greek and Latin writers from the ancient time through the Middle Ages are: Papias of Hierapolis, Justin Martyr, Hippolytus, Irenaeus of Lyon, Origen, Tertullien, Lactance, Eusebius of Caesarea, Didymus of Alexandria, Victorinus of Pettau, Gregory of Nyssa, Jerome, Augustine of Hippo, Quodvultdeus, Primasius, Caesarius of Arles, Gregory the Great, Isidore of Seville, Raban Maur, Bede the Venerable, Ambroise Autpert, Beatus of Liébana, Rupert of Deutz, Joachim of Fiore, Richard of Saint-Victor.

It is well known that, between the years 200 B.C. and 150 A.D., prophetic writings appeared in certain Jewish or Christian circles. These prophetic writings were called Apocalypses. After a careful analysis, this article hypothesizes that the Bible is influenced by this ancient apocalyptic literature.

The Biblical Apocalyptic Literature was dependent upon formularies and expressions used in the ancient Apocalyptic Literature. Some symbols or apocalyptic numbers were accepted from the ancient Literature, sometimes diminishing and sometimes enlarging their meaning. On the basis of formularies and symbols from Biblical Apocalyptic, the Fathers of the Church built their own historical-theological interpretation of eschatological events. In the Bible, both Old and New Tes- 
taments, there are prophetic announcements and eschatological visions. The New Testament is a repetition of those visions and those announcements made in the Old Testament. The Book of Revelation is the conclusion of those announcements and the accomplishment of those visions.

An example of this use of the apocalyptical symbols in the theological and historical contexts by the Christian writers is found in the interpretation of the vision of Gog and Magog. The vision of the Gog and Magog was usually interpreted in the historical context. They were identified with Goths, Barbaric people who invaded and conquered most of the Roman Empire in the $3 \mathrm{rd}, 4^{\text {th }}$, and $5^{\text {th }}$ centuries. Yet this epic figure is reinterpreted with the turn of each new century. In the new historical context, the writers give a new interpretation, but the theology of these symbols remains the same.

Key words: Antichrist, Apokalypse, Gog, Magog, end of times.

Slowa kluczowe: Antychryst, Apokalipsa, Gog, Magog, kres czasów. 
